Retention:

Permanent

\title{
Chronic Zinc Screening Water Effect Ratio for the H-12 Outfall, Savannah River Site
}

\author{
Daniel P. Coughlin, Brian B. Looney and Margaret R. Millings
}

\section{JANUARY 12, 2009}

Savannah River National Laboratory

Savannah River Nuclear Solutions

Aiken, SC 29808

Prepared for the U.S. Department of Energy Under Contract Number DE-AC09-08SR22470






\section{DISCLAIMER}

This work was prepared under an agreement with and funded by the U.S. Government. Neither the U. S. Government or its employees, nor any of its contractors, subcontractors or their employees, makes any express or implied:

1. warranty or assumes any legal liability for the accuracy, completeness, or for the use or results of such use of any information, product, or process disclosed; or

2. representation that such use or results of such use would not infringe privately owned rights; or

3. endorsement or recommendation of any specifically identified commercial product, process, or service.

Any views and opinions of authors expressed in this work do not necessarily state or reflect those of the United States Government, or its contractors, or subcontractors.

Printed in the United States of America

Prepared for

U.S. Department of Energy 
Retention:

Permanent

\title{
Chronic Zn Screening WER for the H-12 Outfall, Savannah River Site
}

\author{
Daniel P. Coughlin, Brian B. Looney and Margaret R. Millings \\ Savannah River National Laboratory, Aiken, SC 29802
}

JANUARY 12, 2009

Savannah River National Laboratory

Savannah River Nuclear Solutions

Savannah River Site

Aiken, SC 29808

Prepared for the U.S. Department of Energy Under

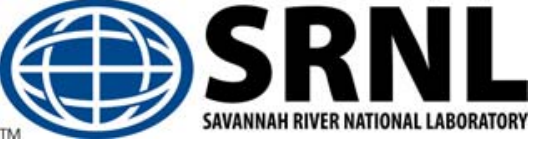

Contract Number DE-AC09-08SR22470 
SRNS-STI-2009-00012, Revision 0

Page ii of vi

\section{REVIEWS AND APPROVALS}




\section{TABLE OF CONTENTS}

Executive Summary .................................................................. 1

$1.0 \quad$ Introduction .................................................................. 1

2.0 Methods ..................................................................... 1

$3.0 \quad$ Results ....................................................................... 3

4.0 Discussion .................................................................. 3

5.0 Conclusions ................................................................. 4

6.0 References ...................................................................... 4

Appendices:

A. ETT Screening WER Report for H-12 Outfall ................... 5

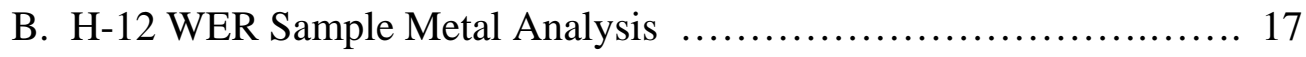

C. Report on Recalculation Procedure for Zinc: NPDES Outfall H-12 ... 19 
SRNS-STI-2009-00012, Revision 0

Page iv of vi

\section{LIST OF FIGURES}

Figure 1. NPDES H-12 sampling station............................. 
SRNS-STI-2009-00012, Revision 0

Page v of vi

\section{LIST OF ACRONYMS}

$\begin{array}{ll}\text { BML } & \text { Biotic Ligand Model } \\ \text { DOC } & \text { Dissolved Organic Carbon } \\ \text { NPDES } & \text { National Pollutant Discharge Elimination System } \\ \text { SRNL } & \text { Savannah River National Laboratory } \\ \text { SRS } & \text { Savannah River Site } \\ \text { WER } & \text { Water Effects Ratio }\end{array}$


SRNS-STI-2009-00012, Revision 0

Page vi of vi

\{blank page 


\section{Executive Summary}

In response to proposed Zn limits for the NPDES outfall $\mathrm{H}-12$, a $\mathrm{Zn}$ screening Water Effects Ratio (WER) study was conducted to determine if a full site-specific WER is warranted. Using standard assumptions for relating the lab results to the stream, the screening WER data were consistent with the proposed $\mathrm{Zn}$ limit and suggest that a full WER would result in a similar limit. Addition of a humate amendment to the outfall water reduced Zn toxicity, but the toxicity reduction was relatively small and unlikely to impact proposed Zn limits. The screening WER data indicated that the time and expense required to perform a full WER for $\mathrm{Zn}$ is not warranted.

\subsection{Introduction}

To support National Pollutant Discharge Elimination System (NPDES) permit development at the Savannah River Site (SRS), limits for Zn were proposed based on a simplified "recalculation" method. The recalculation was performed in 2007 resulting in a proposed limit for $\mathrm{Zn}$ of $153.2 \mu \mathrm{g} / \mathrm{L}$. The recalculation procedure simplifies data requirements, focusing on a few dominant mechanisms that reduce toxicity in outfalls and surface water (U.S. EPA 1985). A WER has the capability to account for a broader array of potential detoxifying processes in the outfall water and can help refine discharge limits. Due to the high cost and extended timeframe required for a full WER, a screening WER is usually performed first to determine if the WER is likely to substantively alter the limits developed using recalculation.

The screening WER is performed similarly to a full WER except that it is based on a single sample rather than samples collected over time to represent the varying real-world conditions. This particular WER study was also modified to include a preliminary assessment of the impact of dissolved organic carbon (DOC) amendment on Zn toxicity. SRS is currently designing a DOC amendment system to mitigate copper toxicity in the H-12 outfall. The screening WER was performed in accordance with the Interim Guidance on Determination and Use of WaterEffect Ratios for Metals (U.S. EPA 1994); a determination that the expense and time required for a full site-specific WER is warranted is dependent on a screening WER result that would indicate the potential for modifying (increasing) the proposed permit limits for $\mathrm{Zn}$ while assuring environmental protection requirements are met.

\subsection{Method}

Outfall H-12 is located near the junction of Road 4 and Road E at the Savannah River Site. It flows south for approximately $750 \mathrm{ft}$ where it merges with an unnamed tributary that also receives discharges from the $\mathrm{H}-08$ outfall. The combined stream flows freely for a distance of about $1500 \mathrm{ft}$ to an extension of the Four Mile Branch (FMB) swamp.

On August 5, 200820 liters of raw H-12 effluent was collected directly from the NPDES H-12 sampling platform (Figure 1). A peristaltic pump with the siphon suspended in the channel's water column was used to prevent the collection or disturbance of sediment. The sample collection corresponded with a release of the H-Area Segregated Cooling Basin (281-5H). The 
sample was immediately chilled and transported to the Savannah River National Laboratory (SRNL) where half of it was treated with $3.39 \mathrm{mg} / \mathrm{L}$ organic carbon using a commercially available potassium humate solution (Huma $\mathrm{K}^{\odot}$, Land and Sea Organics, Modesto CA). The DOC treatment used in this study was intended to mimic the operation of the carbon injection system soon to be built for the mitigation of copper toxicity at the H-12 outfall (Millings et al., 2008). The quantity of amendment added to the treated samples was determined using the Biotic Ligand Model (BLM) Windows Interface Version 2.2.1 (Hydroqual, 2007); the amendment interacts with the copper and reduces chronic toxicity for copper levels up to $25 \mathrm{ug} / \mathrm{L}$. The results of the BLM indicated that the quantity of Huma $\mathrm{K}^{\odot}$ amendment required is a function of $\mathrm{pH}$ and the simplified equation for required dose is:

$$
\begin{aligned}
\mathrm{C}_{\text {target }} & =\left\{\left(9.465 \times 10^{11}\right)\left(\mathrm{H}^{+}\right)^{2}+\left(1.690 \times 10^{7}\right)\left(\mathrm{H}^{+}\right)+1.108\right\} / 0.96 \\
& =\left\{\left(9.465 \times 10^{11}\right)\left(10^{-\mathrm{pH}}\right)^{2}+\left(1.690 \times 10^{7}\right)\left(10^{-\mathrm{pH}}\right)+1.108\right\} / 0.96
\end{aligned}
$$

Where:

$\mathrm{C}_{\text {target }}$ is the desired amendment concentration in the treated wastewater (mg DOC/L)

$\mathrm{C}_{\text {stock }}$ is the amendment concentration in the storage tank (mg DOC/L)

This equation was the basis for the amendment dose (3.39 mg/L organic carbon) at a pH of 6.9, as measured in the August 5, 2008 sample of $\mathrm{H}-12$ effluent.

A chronic Zn screening WER was conducted by ETT Environmental, Inc. in Greer, SC (Appendix A). This study evaluated the toxicity of both the raw $\mathrm{H}-12$ sample and the amended H-12 sample relative to standard laboratory water. For each type of water, the test organism Ceriodaphnia dubia was exposed to varying levels of added Zn. Based on the reproduction of $C$. dubia at the different $\mathrm{Zn}$ levels, a maximum Zn concentration that met a predetermined toxicity target was determined for each water type and adjusted to a constant hardness. The ratio of the result for each test water to the result for the laboratory standard water (water effects ratio) provides a measure of the non-hardness biogeochemistry in the tested water that reduces (or increases) toxicity. WER values greater than 1 indicate that zinc exhibits less toxicity in the tested water than in the laboratory water. As the screening WER result increases, zinc toxicity decreases in the test water. A sub-sample of the untreated water was analyzed for copper at the Environmental/Bioassay Laboratory on the Savannah River Site (Appendix B). 


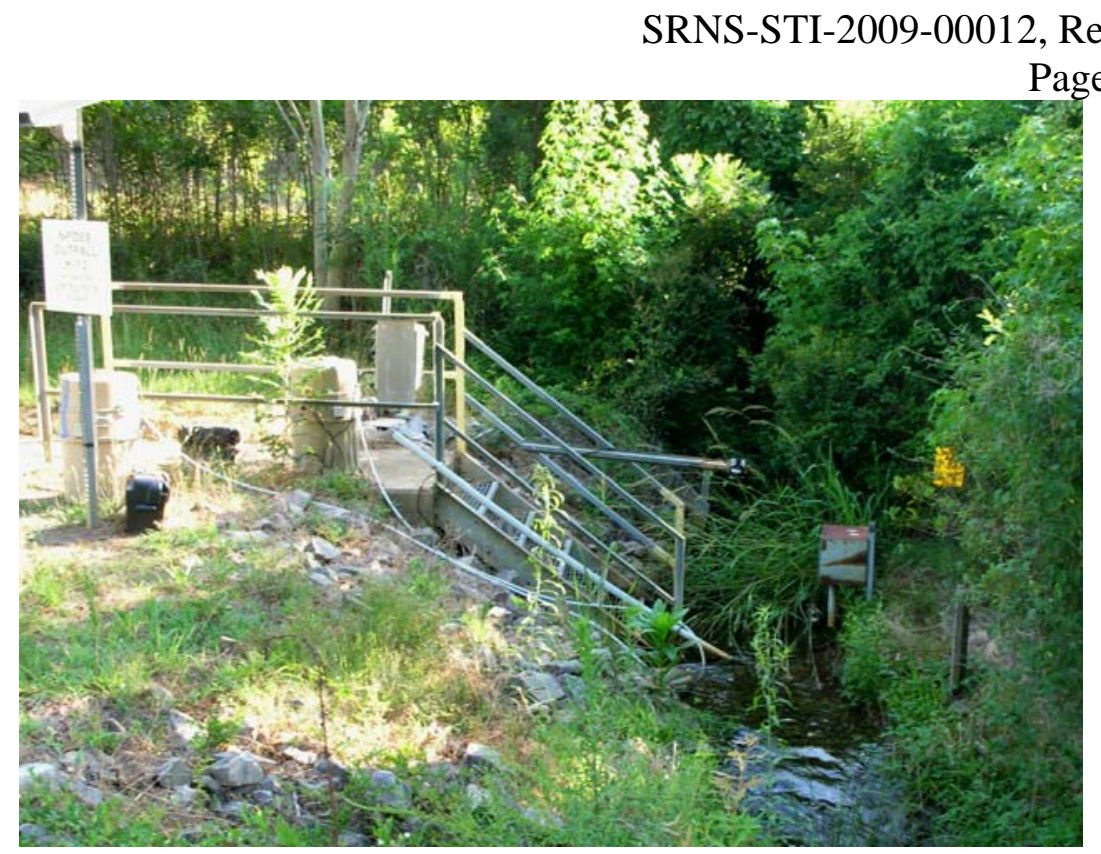

Figure 1. NPDES H-12 sampling station

\subsection{Results}

The study determined the untreated effluent has a WER value of 5.35 while the DOC treated water has a WER value of 7.24. That is a 1.34 fold reduction in Zn toxicity for the DOC treated effluent at the laboratory standard water hardness of $50 \mathrm{mg} / \mathrm{L}$. Applying the screening WER outcomes to the outfall conditions (e.g., flow rates, hardness, etc.) results in an approximate average permit limit of $122 \mu \mathrm{g} / \mathrm{L} \mathrm{Zn}$ for the untreated effluent and $168 \mu \mathrm{g} / \mathrm{L} \mathrm{Zn}$ limit for the DOC treated discharge. A full site specific WER using multiple samples over time, representing a range of outfall conditions, would be needed to support a WER-based permit limit. The copper concentration of the $\mathrm{H}-12$ water used in this study was $<25 \mu \mathrm{g} / \mathrm{L}$ and not likely to have affected the results of the Zn screening WER, particularly for the carbon amended sample.

\subsection{Discussion}

A proposed average permit limit for $\mathrm{Zn}$ in the $\mathrm{H}-12$ outfall, $153.2 \mu \mathrm{g} / \mathrm{L}$, was previously developed based on a standard recalculation procedure (Appendix C). A central goal of the standard recalculation procedure was to provide a reasonable and technically defensible approach for estimating permit limits, and an approach that can be applied cost effectively so that a full WER is not required for every outfall. The recalculation procedure simplifies the data requirements and focuses on some of the dominant mechanisms that reduce toxicity in outfalls and surface water. Prima facie differences between the outcome for the recalculation procedure and the outcome from a WER are the result of differences/simplifications in standardized assumptions (e.g., hardness is treated differently in the two approaches and suspended solids are emphasized in the recalculation). Importantly, the WER has the capability to account for a broader array of potential detoxifying processes in the outfall water - processes such as the impact of the DOC amendment. Due to the high cost and extended timeframe required for a full WER, many sites apply a stepwise decision process in which: 1) a recalculation procedure is performed, 2) (if there is a potentially significant unquantified detoxification process) perform a 
screening WER to determine if the recalculation procedure has adequately represented the water chemistry, and 3) perform a full WER only if the results of the screening WER and the recalculation procedure are significantly different.

\subsection{Conclusions}

While the DOC amendment reduced Zn toxicity, the screening WER results do not warrant performing a full WER. The proposed $\mathrm{H}-12 \mathrm{Zn}$ limit of $153.2 \mu \mathrm{g} / \mathrm{L}$ is bounded by the results of the screening WER of $122 \mu \mathrm{g} / \mathrm{L}$ and $168 \mu \mathrm{g} / \mathrm{L}$ for untreated and treated waters, respectively. The data suggest that the recalculation procedure provides a reasonable and appropriate basis for developing a Zn limit and that a full WER would result in a similar limit and would require significant time and expense to perform.

\subsection{References}

HydroQual, Inc, 2007. User's Guide and Reference Manual for Biotic Ligand Model, Windows Interface, Version 2.2.1, February 2007.

Millings, M. R., B. B. Looney, N. V. Halverson and R. L. Nichols. 2008. Detoxification of Copper in Surface Water Discharges Using Soluble Humic Acid Amendment: Technical Summary of Results. Washington Savannah River Company report WSRC-STI-2008-00105.

U.S. EPA. 1985. Guidelines for Deriving Numerical National Water Quality Criteria for the Protection of Aquatic Organisms and Their Uses. PB85-227049. National Technical Information Service, Springfield, VA.

U.S. EPA. 1994. Interim Guidance on Determination and Use of Water-Effect Ratios for Metals. EPA-823-B-94-001 or PB94-140951. National Technical Information Service, Springfield, VA. 
SRNS-STI-2009-00012, Revision 0

Page 5 of 57

Appendix A

ETT Screening WER Report for H-12 Outfall 


\title{
Screening Tests to Determine the Feasibility of Conducting a Water Effect Ratio for Adjustment of Zinc Limits
}

\section{Outfall: WSRC H-12}

\author{
Metal: Zinc \\ Test Type: Chronic Survival and Reproduction Test \\ Test Species: Ceriodaphnia dubia
}

September 2008

Amended 9/22/08 


\subsection{Introduction}

\section{SRNS-STI-2009-00012, Revision 0}

In response to the anticipated proposed limits in the draft permit, screening studies were initiated to determine whether a Site Specific / WER studies would be likely to significantly increase permit limits for zinc. A screening WER was conducted for untreated H-12 effluent and H-12 effluent which was spiked with Dissolved Organic Carbon (DOC). This report presents the result of the screening studies.

\subsection{Methods}

A WER involves comparing the toxic level of a metal in laboratory water to the toxic level of a metal in site water. In this study Diluted Mineral Water (DMW) at a hardness of $50 \mathrm{mg} / \mathrm{L}$ was used as the "laboratory water”. Because laboratory water contains no natural chelating agents which can bind aquatic metals and make them less biologically available, metals such as zinc tend to be toxic at lower concentrations than they are in natural site waters. Downstream water is typically a mixture of effluent and upstream water. In this study $100 \%$ effluent was used as site water, because it is the In-Stream Wastewater Concentration (IWC).

\section{$2.1 \quad$ Preparation of Test Solutions}

\subsubsection{Laboratory Water}

Due to an adequate database of test results of zinc in laboratory water which has been developed at ETT Environmental, no additional tests were needed. Existing data was used.

\subsubsection{Simulated Downstream Water}

Simulated downstream water was $100 \%$ effluent. Zinc was spiked into untreated effluent and effluent spiked with DOC at a series of seven test concentrations. It was spiked from a stock solution of $50 \mathrm{mg} / \mathrm{L}$ of zinc sulfate $\mathrm{ZnSO}_{4} 7 \mathrm{H}_{2} \mathrm{O}(11.37 \mathrm{mg} / \mathrm{L}$ as $\mathrm{Zn})$. The volumes of stock solution added were as follows; 


\begin{tabular}{|c|c|c|}
\hline Test Concentration & $\underline{\text { mL Stock Soln. }}$ & $\begin{array}{r}\text { SRNS-STI-2009-00012 } \\
\text { Total Volume (mL) }\end{array}$ \\
\hline 0 ug/L (Control) & 0 & 1400 \\
\hline $34.3 \mathrm{ug} / \mathrm{L}$ & 4.22 & 1400 \\
\hline 49 ug/L & 6.03 & 1400 \\
\hline 70 ug/L & 8.62 & 1400 \\
\hline $100 \mathrm{ug} / \mathrm{L}$ & 12.31 & 1400 \\
\hline $143 \mathrm{ug} / \mathrm{L}$ & 17.51 & 1400 \\
\hline 204 ug/L & 25.12 & 1400 \\
\hline
\end{tabular}

\section{$2.2 \quad$ Metal Analyses}

Total and dissolved zinc were measured in each test concentration at the beginning of the test. Zinc was measured by an atomic absorption spectrophotometer using method 3111B (Standard Methods $18^{\text {th }}$ Ed.).

\section{$2.3 \quad$ Toxicity Testing}

Chronic Survival and Reproduction tests with the test organism Ceriodaphnia dubia were conducted with each zinc treatment level. The methodology is summarized as follows;

1. Temperature:

2. Light:

3. Test Chamber Size:

4. Test Solution Volume:

5. Renewal:

6. Age of Test Organisms:

7. No. of Neonates / Test Chamber

8. No. Replicates / Dilution

9. Feeding:

10. Cleaning of Test Chambers:

11. Aeration:

12. Dilution Water

13. Effluent Concentrations:

14. Dilution Factor:

15. Test Duration:

16. Test End Point $25^{\circ} \mathrm{C} \&<1$

$100 \mathrm{ft}-\mathrm{cd} ; 16 \mathrm{hr}$ lt/8 hr dk

$30 \mathrm{~mL}$ plastic cup

$15 \mathrm{~mL}$

Daily

$<24$ hours

1

10

Daily with $0.05 \mathrm{~mL}$ Selenastrum and $0.1 \mathrm{~mL}$ YAT

None

None

as noted in 2.1.2

0.7

7 days / 3 broods

EC50 (using non-linear regression) 


\subsection{Results}

3.1 Laboratory Water

Data from previous testing has indicated that zinc is chronically toxic in the $50 \mathrm{mg} / \mathrm{L}$ hardness laboratory water at approximately $66.5 \mathrm{ug} / \mathrm{L}\left(\mathrm{LC}_{50}\right.$ at a hardness of $\left.50 \mathrm{mg} / \mathrm{L}\right)$.

\subsection{Untreated Effluent}

The results for the tests with zinc spiked into untreated H-12 effluent are summarized as follows.

\begin{tabular}{|c|c|c|}
\hline Nominal & Measured & \\
\hline Test & Test & Mean Reproduction \\
\hline Concentration & $\underline{\text { Concentration }}$ & $\underline{\text { Untreated Effluent }}$ \\
\hline 0 ug/L (Control) & 27.6 ug/L T-Zn & 19.5 \\
\hline 34.3 ug/L & 80 ug/L T-Zn & 20.6 \\
\hline $49.0 \mathrm{ug} / \mathrm{L}$ & 85 ug/L T-Zn & 17.2 \\
\hline $70.0 \mathrm{ug} / \mathrm{L}$ & 95 ug/L T-Zn & 2.9 \\
\hline $100 \mathrm{ug} / \mathrm{L}$ & 124 ug/L T-Zn & 0.0 \\
\hline $143 \mathrm{ug} / \mathrm{L}$ & 202 ug/L T-Zn & 0.0 \\
\hline
\end{tabular}

\subsection{DOC treated Effluent}

The results for the tests with zinc spiked into treated H-12 effluent are summarized as follows.

\begin{tabular}{|c|c|c|}
\hline Nominal & Measured & \\
\hline Test & Test & Mean Reproduction \\
\hline Concentration & $\underline{\text { Concentration }}$ & $\underline{\text { Untreated Effluent }}$ \\
\hline 0 ug/L (Control) & 27.6 ug/L T-Zn & 21.0 \\
\hline $49.0 \mathrm{ug} / \mathrm{L}$ & 77 ug/L T-Zn & 20.4 \\
\hline $70.0 \mathrm{ug} / \mathrm{L}$ & 85 ug/L T-Zn & 19.8 \\
\hline $100 \mathrm{ug} / \mathrm{L}$ & 120 ug/L T-Zn & 11.0 \\
\hline $143 \mathrm{ug} / \mathrm{L}$ & 170 ug/L T-Zn & 4.3 \\
\hline 204 ug/L & 208 ug/L T-Zn & 0.0 \\
\hline
\end{tabular}




\subsection{Determination of Water Effect Ratio}

4.1 Adjustment of Laboratory Water Result to Hardness of Site Water

In order to determine a WER the $\mathrm{EC}_{50}$ values for the laboratory water must be adjusted to the same hardness as the effluent. This is done using the following equation;

(H-12 Untreated)

$$
\begin{aligned}
& \text { Adjusted EC50 }=(\text { Site Hardness/Lab Water Hardness })^{0.8545} * \text { Original EC } \text { E0 }_{50} \\
& \qquad \begin{array}{l}
=(10 / 50)^{0.8545} * 66.5 \mathrm{ug} / \mathrm{L} \\
=16.8 \mathrm{ug} / \mathrm{L} \mathrm{Zn}
\end{array}
\end{aligned}
$$

$($ H-12 DOC Treated $) \quad$ Adjusted EC50 $=(\text { Site Hardness/Lab Water Hardness })^{0.8545} *$ Original EC ${ }_{50}$

$$
\begin{aligned}
& =(10.2 / 50)^{0.8545} * 66.5 \mathrm{ug} / \mathrm{L} \\
& =17.1 \mathrm{ug} / \mathrm{L} \mathrm{Zn}
\end{aligned}
$$

\subsection{Calculation of WER}

The WER is calculated as follows; $\quad$ Effluent $\mathrm{LC}_{50} /$ Adjusted Laboratory Water LC $_{50}$

$$
\begin{aligned}
& \text { Untreated Effluent WER }=89.9 / 16.8=5.35 \\
& \text { DOC Treated Effluent WER }=123.8 / 17.1=7.24
\end{aligned}
$$

NOTE: Hardness of the DOC treated effluent was measured as $16 \mathrm{mg} / \mathrm{L}$ by the titrimetric method. However, based on measured concentrations of calcium and magnesium in the DOC, the hardness should have been $10.2 \mathrm{mg} / \mathrm{L}$. According to Standard Methods (20 ${ }^{\text {th }} \mathrm{Ed}$.) suspended or colloidal organic matter may interfere with the end point for the titrimetric method. For the purposes of the calculations in this report the hardness used is $10.2 \mathrm{mg} / \mathrm{L}$. 


\subsection{Predicted Site Specific Limits for Zinc}

The Site Specific Limits for Zinc are calculated as follows;

[(EPA Water Quality Criterion) X (WER)x (Downstream Flow)] - [(Upstream Flow) x (Upstream Zn Conc.)]

(Effluent Flow)

\section{Untreated Effluent}

The EPA Water Quality Criterion (Maximum) for Zinc at the Site Hardness of $10 \mathrm{mg} / \mathrm{L}$ (for untreated effluent) $=17.03 \mathrm{ug} / \mathrm{L}$. Incorporating the results of the Recalculation Procedure the EPA Water Quality Criterion for Zinc at a Site Hardness of $10 \mathrm{mg} / \mathrm{L}$ is adjusted to $22.88 \mathrm{ug} / \mathrm{L}$.

The WER is 5.35

Downstream flow $=$ effluent flow.

The 7Q10 upstream flow is 0 mgd $=0$ cfs.

The default upstream zinc concentration to be used $0 \mathrm{mg} / \mathrm{L}$.

Using the formula above, the Predicted Average Site Specific Limit is $0.122 \mathrm{mg} / \mathrm{L} \mathrm{Zn}$.

\section{DOC Treated Effluent}

The EPA Water Quality Criterion (Maximum) for Zinc at the Site Hardness of $10.2 \mathrm{mg} / \mathrm{L}$ (for untreated effluent) $=17.32 \mathrm{ug} / \mathrm{L}$. Incorporating the results of the Recalculation Procedure the EPA Water Quality Criterion for Zinc at a Site Hardness of $10.2 \mathrm{mg} / \mathrm{L}$ is adjusted to $23.27 \mathrm{ug} / \mathrm{L}$.

The WER is 7.24

Downstream flow $=$ effluent flow.

The 7Q10 upstream flow is $0 \mathrm{mgd}=0 \mathrm{cfs}$.

The default upstream zinc concentration to be used $0 \mathrm{mg} / \mathrm{L}$.

Using the formula above, the Predicted Average Site Specific Limit is 0.168 mg/L Zn.

\subsection{Conclusion}

If a full chronic Water Effect Ratio for Zinc is conducted, it is predicted that the new average permit limit will be $\mathbf{0 . 1 2 2} \mathbf{~ m g / L}$ for untreated H-12 effluent and $\mathbf{0 . 1 6 8} \mathbf{~ m g} / \mathbf{L}$ for DOC treated effluent. As compared to the current permit limit of $0.100 \mathrm{mg} / \mathrm{L}$, it may be predicted that a Zinc WER will raise permit limits for untreated effluent. However, a Zinc WER will be more effective to raise permit limits if the effluent is 
SRNS-STI-2009-00012, Revision 0

treated with DOC. SCDHEC has the authority to arbitrarily reduce the limit based upon their determination of "what is needed".

\section{Attachment}

\section{Bench Sheets for Screening WER}


SRNS-STI-2009-00012, Revision 0

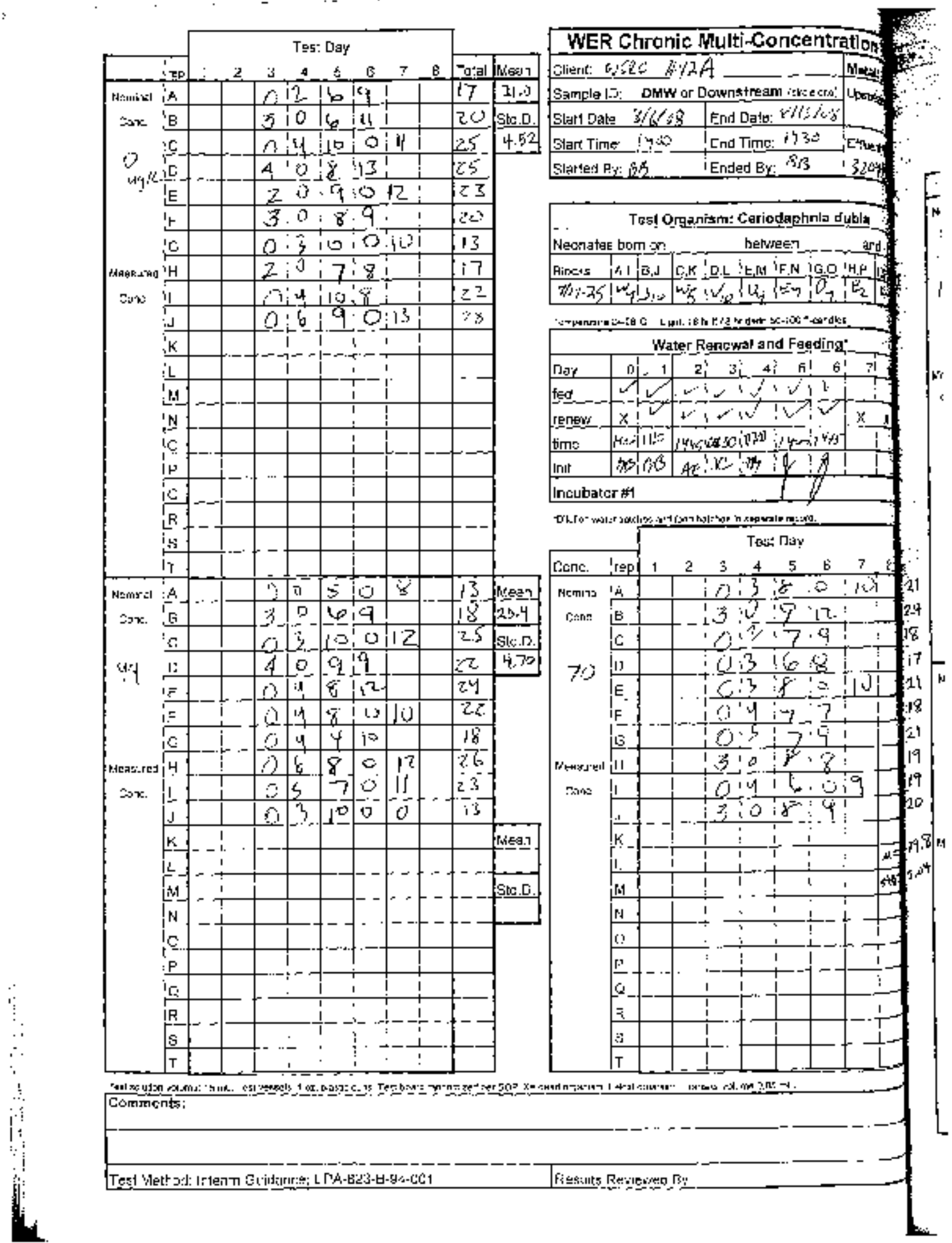


SRNS-STI-2009-00012, Revision 0

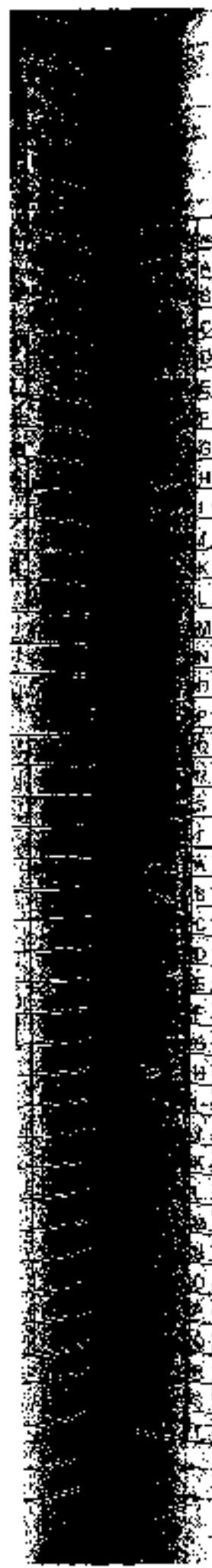

\begin{tabular}{|l|}
\hline WER Chronic Multi-Concentration Test \\
\hline Continued: $1 ! \cdot R A$ \\
\hline
\end{tabular}

AES: las? DAY 1
2

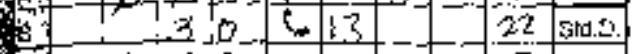

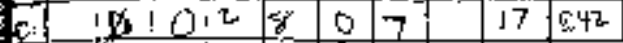

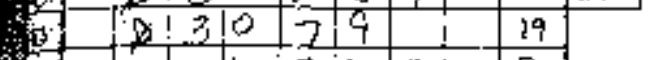

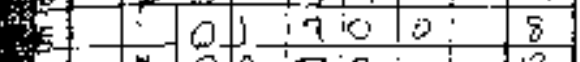

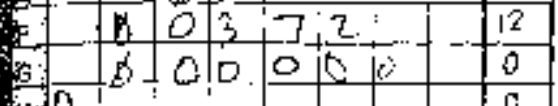
in 1 i $14599+9$

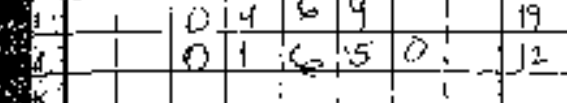
\begin{tabular}{l|l|l|l|l|l|l|}
\hline \\
\hline
\end{tabular} , is : $:-1-\div-\frac{1}{1}$ Preparation of Dowenstreatm Water:

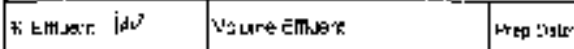

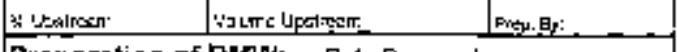
Preparation of DMW: _Ditu PIeperad:

\begin{tabular}{|c|c|c|c|}
\hline 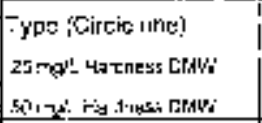 & SATr: 2MUV & TIlal Kol & บท \\
\hline 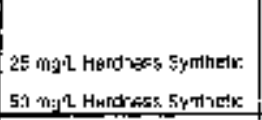 & Wisumi RAH.SF & 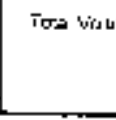 & me \\
\hline Metäl Spiking & 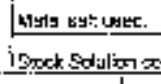 & $\frac{1}{1 / 3 \sigma_{1}}$ & \\
\hline  & 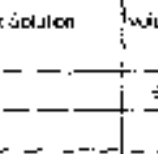 & 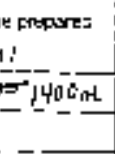 & 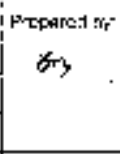 \\
\hline$\frac{153}{25}+\frac{1235}{1751}$ & & &  \\
\hline
\end{tabular}

\begin{tabular}{cccc} 
& & & 1 \\
\hline & & - & $i$
\end{tabular}

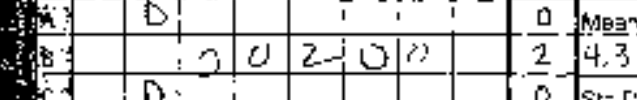

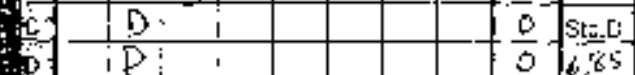
o $0: 0 ! 200-0,65$ i $D+i=1$

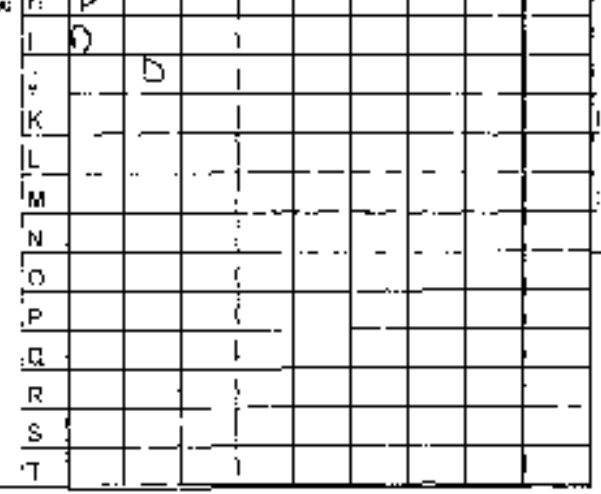


SRNS-STI-2009-00012, Revision 0

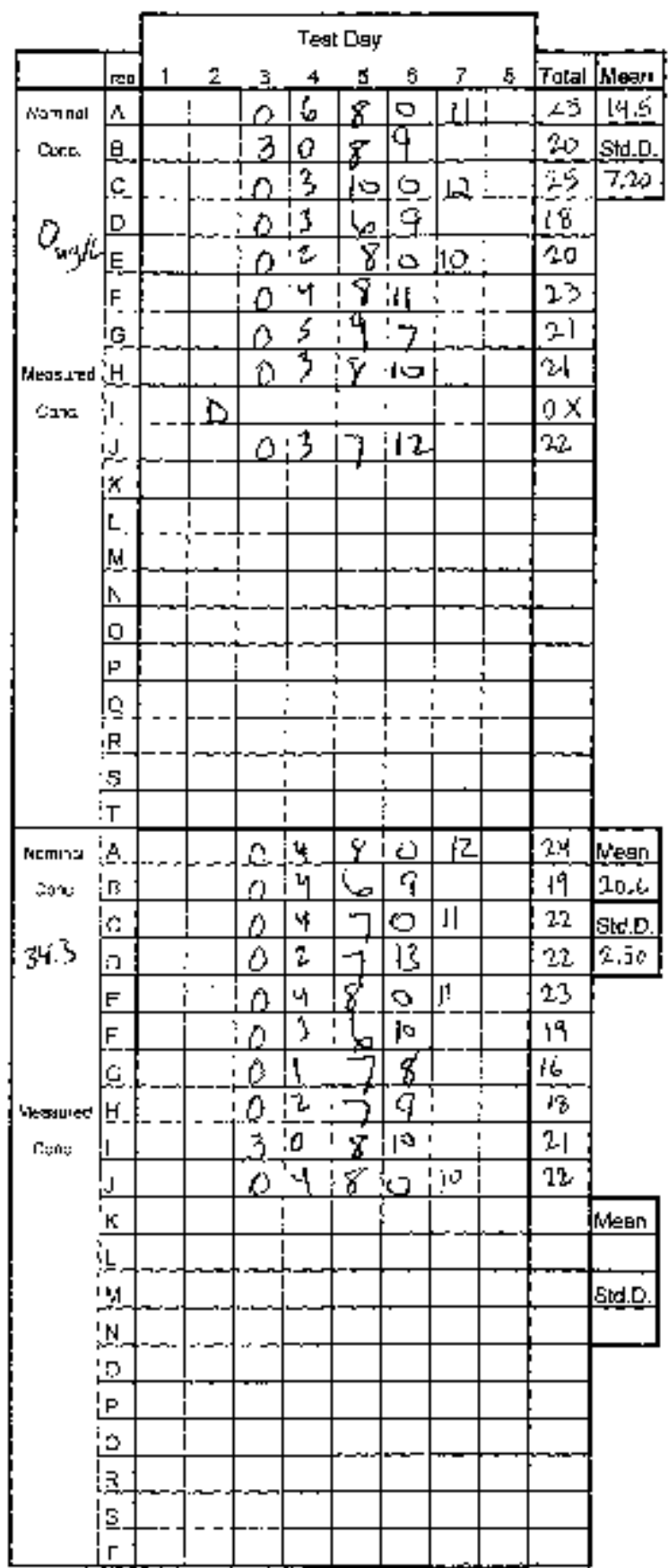

WER Chronjc Mujti-Concentratio Clierril:

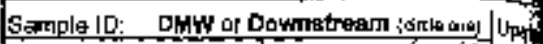





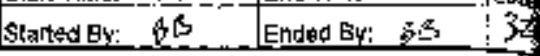



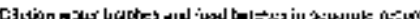

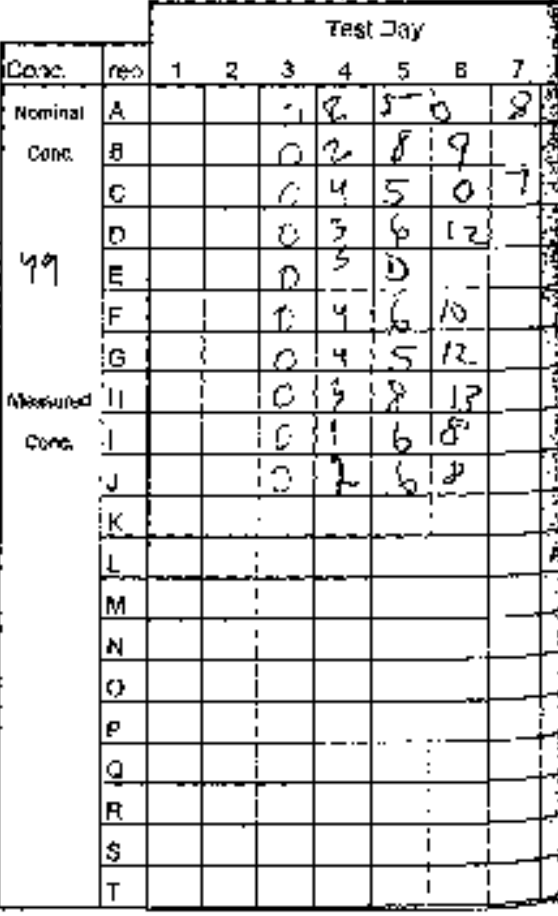

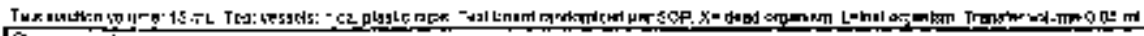
Commints:

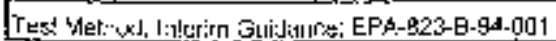
Resolls Revicised by: 
SRNS-STI-2009-00012, Revision 0 .

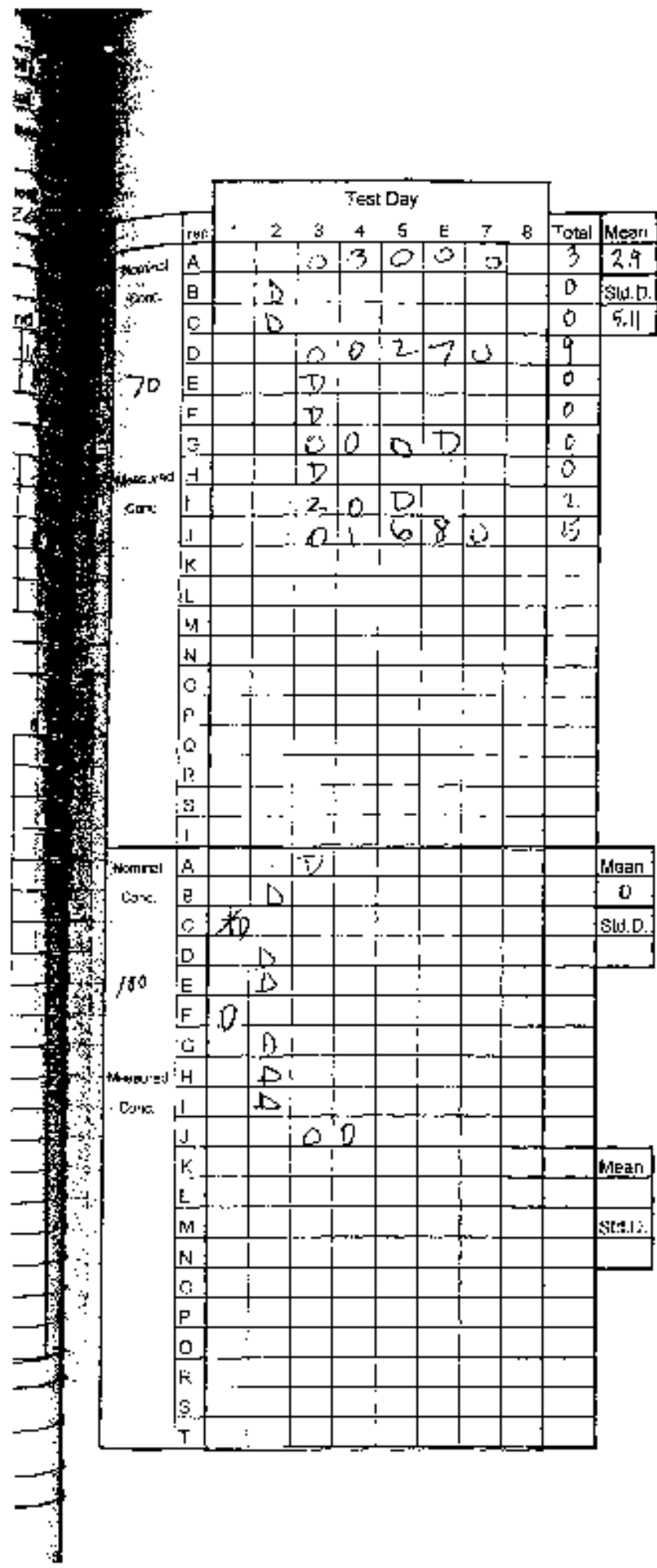

\begin{tabular}{|l|}
\hline WER Chronic Multi-Concentration Test \\
\hline Continueg: \\
\hline $1-$ - 2 -
\end{tabular}

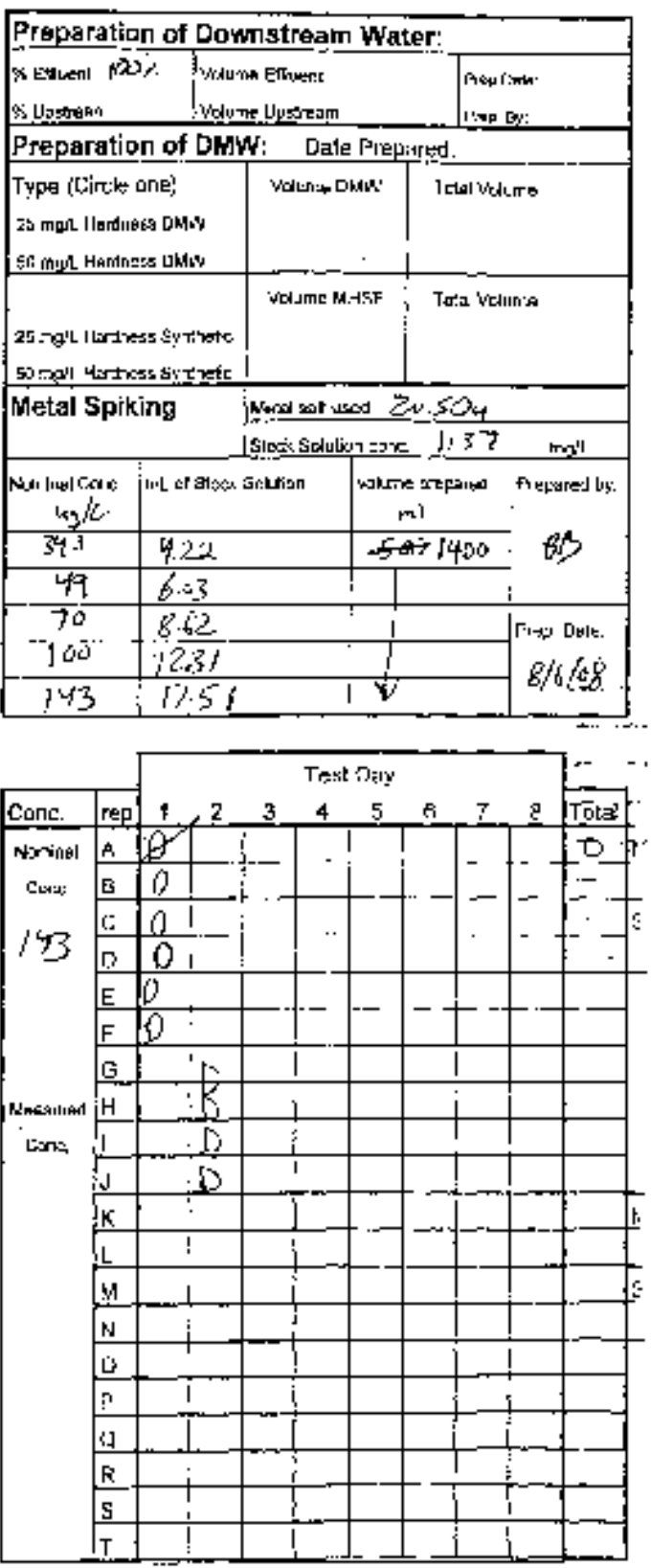


SRNS-STI-2009-00012, Revision 0

Page 17 of 57

\section{Appendix B}

\section{H-12 WER Sample Metal Analysis}

(Environmental/Bioassay Laboratory) 


\section{SRNS-STI-2009-00012, Revision 0}

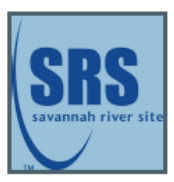

Savannah River Site's

Analytical Laboratories

Environmental/Bioassay Laboratory

NPDES

\section{CERTIFICATE OF ANALYSIS}




SRNS-STI-2009-00012, Revision 0

Page 19 of 57

Appendix C.

Report on Recalculation Procedure for Zinc: NPDES Outfall H-12 




P.O. Box 16414, Greenville, SC 29606
(864) 877-6942 . FAX (864) 877-6938

Craftsman Court, Greer, SC 29650

\section{RECALCULATION PROCEDURE for ZINC}

NPDES Outfall H-12

Conducted for Westinghouse Savannah River Company

Contract \# 383922N

August 2007

Amended 1/9/08 (Rev. 4) 
TABLE OF CONTENTS

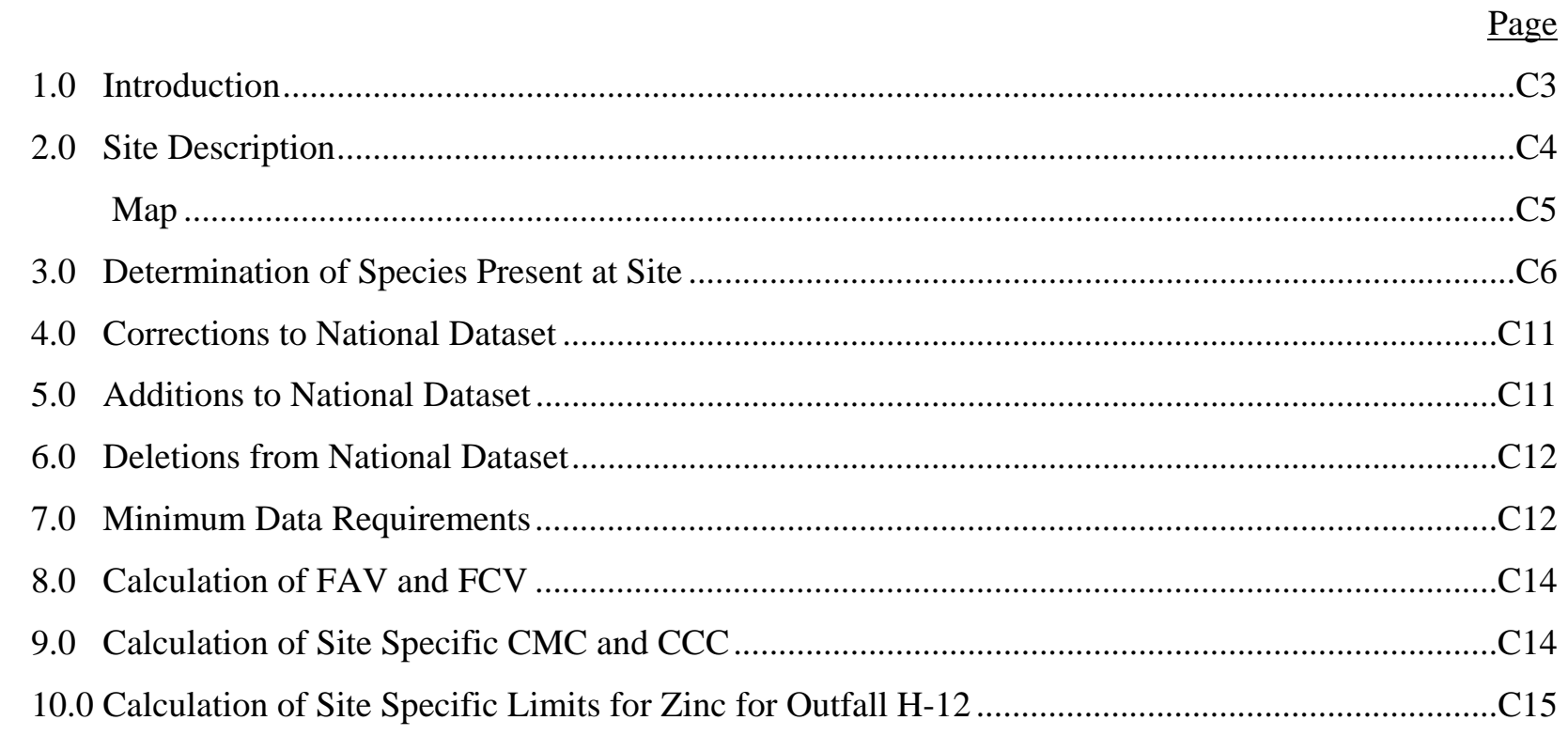

Appendix A. National DataSet for Zinc

Appendix B. Deletion Process

Appendix C. Site Specific Data Set and Calculations of FAV and FCV

Appendix D. EPA Recalculation Procedure Protocol 


\subsection{Introduction}

As permitted under the NPDES permit, a Recalculation Procedure was conducted for Zinc at WSRC Outfall H-12. The methodology used included Interim Guidance on Determination and Use of WaterEffect Ratios for Metals (EPA-823-B-94-001 Appendix B) and Guidelines for Deriving Numerical National Water Quality Criteria for the Protection of Aquatic Organisms and Their Uses by Stephan et al. 


\subsection{Site Description}

\section{SRNS-STI-2009-00012, Revision 0}

Outfall H-12 is located near the junction of Road 4 and Road E at the Savannah River Site. It flows south for approximately $750 \mathrm{ft}$ where it merges with the unnamed tributary that also receives from the H-08 outfall and originates approximately 2/3 mile ESE of the H-12 Outfall. The unnamed tributary is a water of the state. The combined stream flows freely for a distance of about 1500 feet to where it enters a swampy lentic zone, which forms an extension of the Four Mile Branch (FMB) swamp. For the purposes of this study, this area is not considered to be part of the stream. Four Mile Branch is a second-order stream with a low flow of approximately 1.5 cfs.

The upper sections of the $\mathrm{H}-12 / \mathrm{H}-08$ stream reach are deeply eroded, with a largely hardclay stream bed (Figure 1). There are no rocks but the stream bed is littered with chunks of hard clay forming continuous riffle. The depth is only a few inches and the width of the stream is about ten feet. The steep banks are 10-15 feet high, at the top of which deciduous forest


predominates. Near the point at which the stream reaches the swamp, the stream cuts less deeply into the ground and the height of the banks decreases to only 3-5 feet. In this section there is some silt benthic habitat and a slower flow. 
SRNS-STI-2009-00012, Revision 0

AERIAL VIEW OF SITE

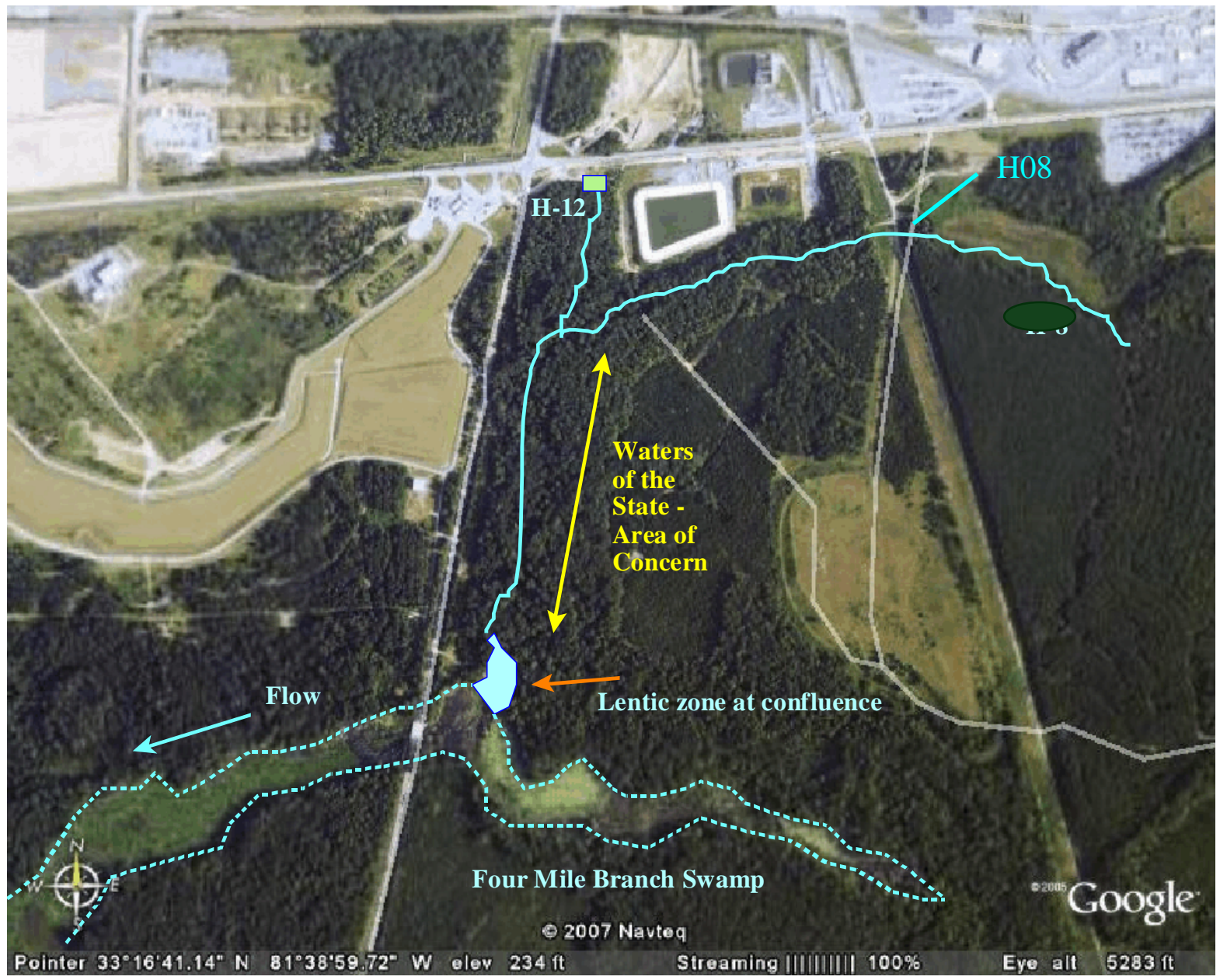




\section{SRNS-STI-2009-00012, Revision 0}

\subsection{Determination of Species Present at the Site}

According to the Recalculation Procedure, all species in the National Database for a particular metal which occur at a site must be retained in the list. Species which occur at a site are defined as 1) species which are usually present at the site, 2) species present only seasonally, 3) species present intermittently due to range fluctuations, 4) species known to be present in the past but are no longer present due to habitat degradation, and 5) species present in nearby bodies of water and would be expected to be present in the absence of habitat degradation.

Studies of the aquatic fauna, both fish and aquatic macroinvertebrates, have been conducted.

The following species of fish were collected in the stream during sampling in September 2005 (data provided by Michael Paller of WSRC).

Family Cyprinidae

$\begin{array}{ll}\text { Nocomis leptocephalus } & \text { Bluehead Chub } \\ \text { Notemigonus chrysoleucas } & \text { Golden Shiner } \\ \text { Notropis lutipinnis } & \text { Yellowfin Shiner }\end{array}$

$\underline{\text { Family Ictaluridae }}$

$\begin{array}{ll}\text { Ameiurus natalis } & \text { Yellow bullhead } \\ \text { Noturus insignis } & \text { Margined Madtom } \\ \text { Noturus leptacanthus } & \text { Speckled Madtom }\end{array}$

Family Esocidae

Esox americanus

Esox niger

Redfin Pickerel

Chain Pickerel

Family Aphredoderidae

Aphredoderus sayanus Pirate Perch

$\underline{\text { Family Centrarchidae }}$

Lepomis auritus

Lepomis gulosus

Lepomis punctatus

Redbreast Sunfish

Warmouth

Spotted Sunfish 


\section{SRNS-STI-2009-00012, Revision 0}

In addition to the species actually collected in the stream, there are a number of species collected in Four Mile Branch which might also might be expected to occur in the stream or might have occurred in the stream in the past. These species include;

Family Anguillidae

Anguilla rostrata American Eel

Family Cyprinidae

$\begin{array}{ll}\text { Notropis cummingsae } & \text { Dusky Shiner } \\ \text { Notropis hudsonius } & \text { Spottail Shiner } \\ \text { Notropis petersoni } & \text { Coastal Shiner } \\ \text { Pteronotropis hypselopterus } & \text { Sailfin Shiner } \\ \text { Semotilus atromaculatus } & \text { Creek Chub }\end{array}$

Family Catostomidae

$\begin{array}{ll}\text { Erimyzon oblongus } & \text { Creek Chubsucker } \\ \text { Minytrema melanops } & \text { Spotted Sucker }\end{array}$

$\underline{\text { Family Percidae }}$

$\begin{array}{ll}\text { Etheostoma olmstedi } & \text { Tessellated Darter } \\ \text { Percina nigrofasciata } & \text { Blackbanded Darter }\end{array}$

The following species of aquatic macroinvertebrates were collected in the stream during sampling on June 2007 (sampling by ETT Environmental, Inc.).

Order Trichoptera (Caddisflies)

Hydropsyche betteni

Order Megaloptera (Hellgrammites)

Nigronia serricornis

Order Coleoptera (Beetles)

Dineutus sp. (whirligig beetle)

Stenelmis sinuata (elmid beetle)

Order Diptera

Ablabesmyia mallochi (midge)

Chironomus sp. (midge) 


\section{Order Diptera (cont'd)}

\section{SRNS-STI-2009-00012, Revision 0}

Labrundinia pilosella (midge)

Limnophila sp. (crane fly)

Meropelopia sp. (midge)

Paratendipes albimanus (midge)

Phaenopsectra flavipes (midge)

Rheotanytarsus exiguus gp. (midge)

Stenochironomus sp. (midge)

Tipulidae (cranefly pupa)

It was evident from the sample collection that the stream is currently supportive of only a reduced diversity of aquatic macroinvertebrates. One reason is undoubtably the hard clay benthic substrate which is not conducive to macroinvertebrate colonization. In addition to the species actually collected in the stream, there are numerous taxa of aquatic macroinvertebrates which would be expected in a stream of this size at the Savannah River Site. Some of the expected taxa would include;

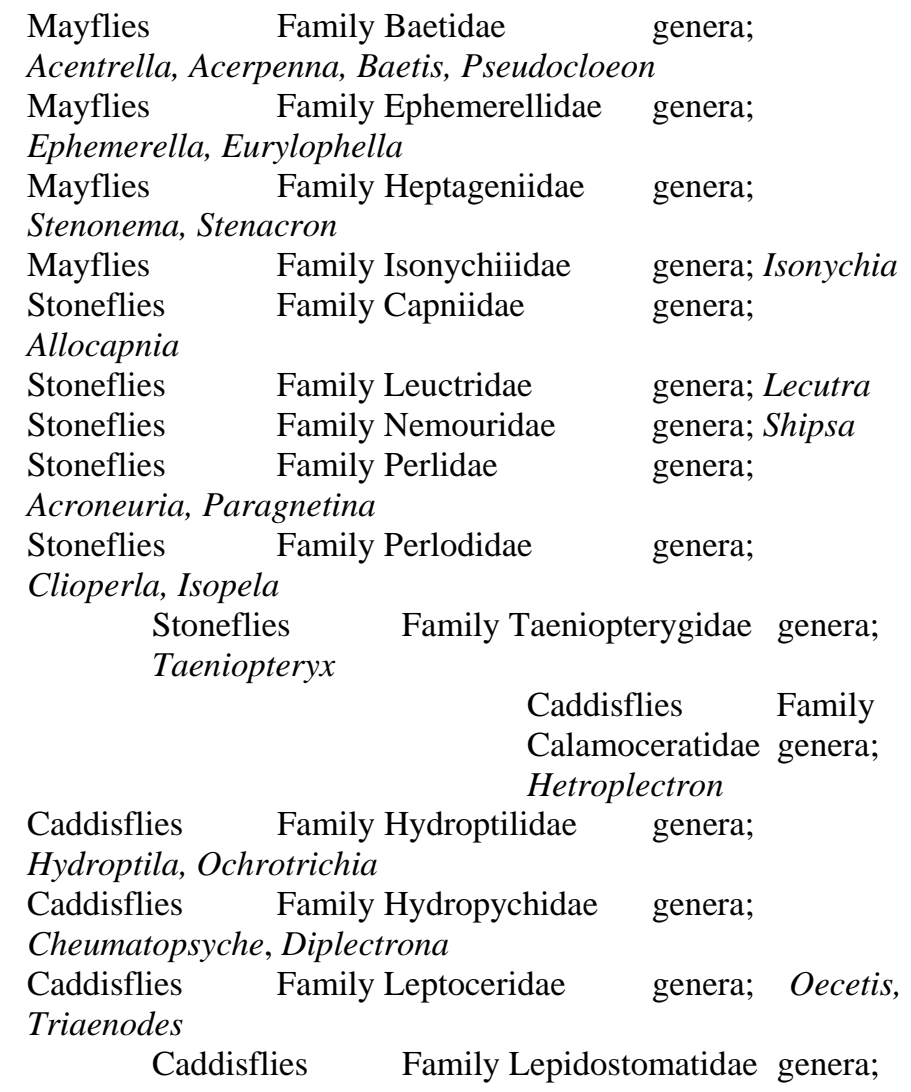




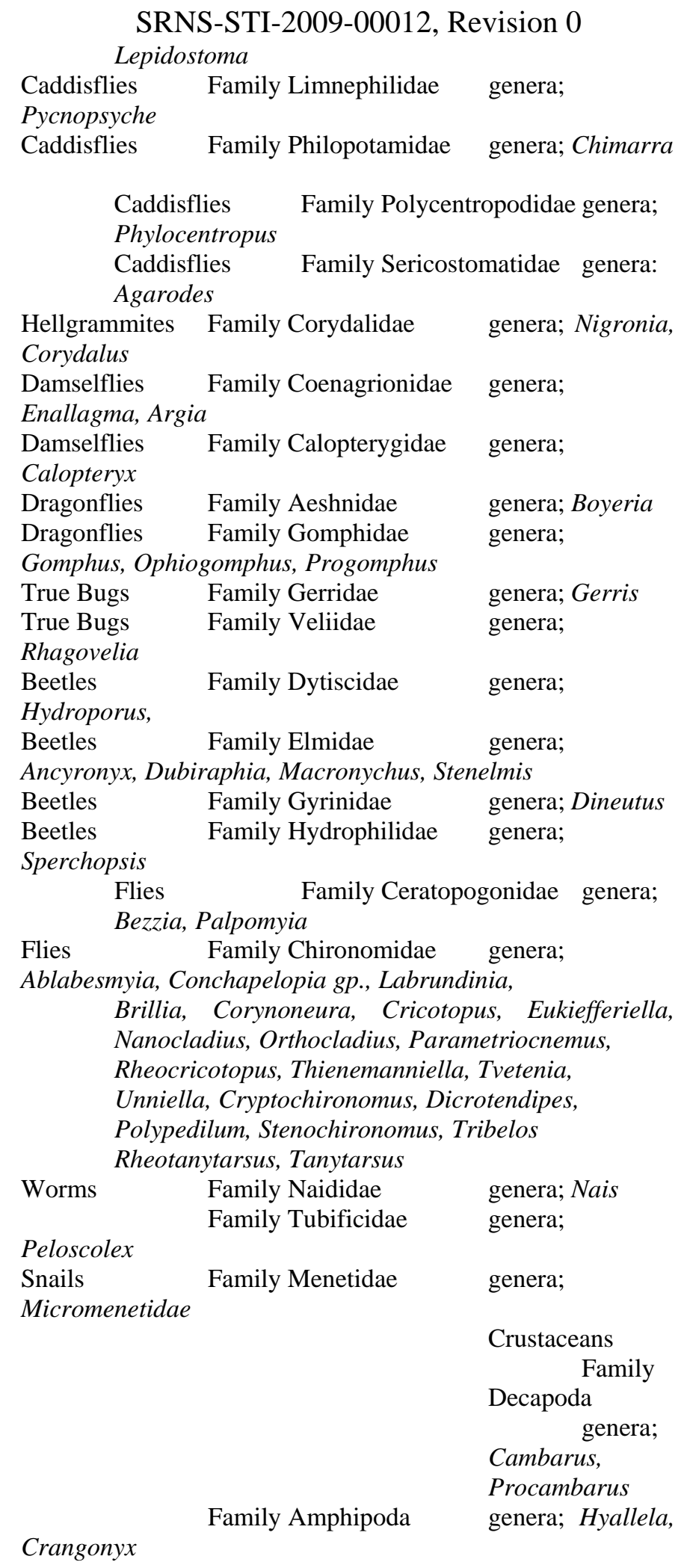




\section{SRNS-STI-2009-00012, Revision 0}

The following comments are provided with regard to species in the National Dataset and their potential for being present at the site;

Daphnidae

Morone saxatilis

Agosia chrysogaster

Oreochromis mossambica Tilapia

Salmonidae

Limnodrilus hoffmeisteri

Pectinatella magnifica

Physella heterostropha

Physella gyrina

Helisoma campanulatum

Plumatella rostrata

Jordanella floridae

Lophopodella carteri

Lirceus alabamae

Pimephales promelas

Xiphophorus maculates

Corbicula fluminea

Catostomus commersonii

Notemigonus crysoleucas

Poecilia reticulata

Ptychocheilus oregonensis Northern

Cyprinus carpio

Gammaridae

H-12 Recalculation Zn
Water fleas. Daphnids are associated with lentic (still water) habitats, which are not naturally present in this stream. Among the daphnids in the national dataset only Ceriodaphnia reticulata might be found in a lentic habitat at the Savannah River Site. Of the other species in the national dataset it may be noted that 1) Daphnia magna is found only in the north and midwest - associated with harder water, 2) Daphnia pulex is found in the north and west but not the Ohio Valley or Southeast, 3) Ceriodaphnia dubia (=affinis) is generally a more northern species. Species of Daphnia which are or would be expected to be present in lentic habitats at the Savannah River Site include Daphnia ambigua, Daphnia catawba, and Daphnia laevis. The H12/H08 stream does not have the type of lentic habitat which would be necessary for the presence of daphnids- therefore daphnids are determined not to be present.

Striped Bass Not present. A coastal species that does not enter small streams.

Longfin Dace Not present. Occurs in Arizona. Non-native species.

Trout,Salmon Onchorhynus, Salvelinus, Salmo. Not present. Salmonids are cold-water fish and do not occur in the lower Piedmont and Coastal Plain of South Carolina.

Worm Widespread in distribution and expected to be found in this stream.

Bryozoan Not present. A northern species

Snail Expected to be present in the stream.

Snail Widespread in distribution. Not reported from Savannah River Site.

Snail Not present. A northern species. = Planorbula.

Bryozoan Status undetermined.

Flagfish Not present. Found only in Florida.

Bryozoan Reported only from the northern United States and

Canada

River Site.

Isopod Not present. Not known from the Savannah

Fathead Not present. A northern and midwest species..

Southern Not present. Not found at the Savannah River Site. Platyfish

Asiatic Clam Non-native species. Present at site.

White Sucker Not present. Not found at Savannah River Site.

Golden Shiner This species has been collected in the stream.

Guppy Non-native species.

America

Pikeminnow. Not present. Found in NW North Carp

Non-native species

Amphipod There are no species of Gammarus present

ETT: 08/07 
Caecidotea sp.

Lumbriculus variegatus

Carassius auratus

Lepomis macrochirus

Lepomis gibbosus

Anguilla rostrata

Amnicola sp.

Snail

Fundulus diaphanus

Nais sp.

Crangonyx pseudogracilis Amphipod Argia sp.

Xenopus laevis

\section{SRNS-STI-2009-00012, Revision 0}

at the site, although species of the closely related Crangonyx are likely present, or may have been in the past.

Isopod This genus likely occurs in the stream. bicrenata occurs in the Tennessee Valley.

Worm Widespread. Likely found at site.

Goldfish Non-native species.

Bluegill Likely to be present at the site.

Pumpkinseed Likely to be present at site.

site.

American Eel Found in Four Mile Branch. May enter the

Amnicola limosus likely to be present at site.

Banded Killifish. Not present. Not found in Savannah River Drainage Worm Species in this genus may be

present.

Not present. A northern species.

Damselfly The species Argia sedula occurs in the stream.

African Clawed Frog Not present. Introduced in SW US

\subsection{Corrections to the National Dataset}

A listing of the National Dataset is provided in Appendix A (Includes 1995 Update). No corrections to the National Dataset are made in this Recalculation Procedure.

\subsection{Additions to the National Dataset}

No additions to the National Dataset are made in this Recalculation Procedure. 


\subsection{Deletions from the National Dataset}

Based upon the deletion process as described in the Recalculation Procedure, the following species are deleted from the National Dataset (See Appendix B);

$\begin{array}{ll}\text { Daphnid } & \text { Ceriodaphnia reticulata } \\ \text { Daphnid } & \text { Ceriodaphnia dubia } \\ \text { Daphnid } & \text { Daphnia pulex } \\ \text { Daphnid } & \begin{array}{l}\text { Daphnia magna } \\ \text { Chinook Salmon }\end{array} \\ \text { Onchorhynchus tshawytscha } \\ \text { Onchorhynchus nerka } \\ \text { Coho Salmon } \\ \text { Rainbow Trout } & \text { Onchorhynchus kisutch } \\ \text { Atlantic Salmon } & \text { Salmo salar } \\ \text { Snail } & \text { Physella gyrina } \\ \text { Tilapia } & \text { Oreochromis mozambica } \\ \text { Brook Trout } & \text { Salvelinus fontinalus } \\ \text { White Sucker } & \text { Catostomus commersonii } \\ \text { Bryozoan } & \text { Lophopodella carteri }\end{array}$

\subsection{Minimum Data Requirements}

The primary Minimum Data Requirement is that after the Deletion Process there must be at least eight families of aquatic invertebrates, amphibians, and fishes at the site. In this Recalculation Procedure there were 12 families of aquatic invertebrates retained and 5 families of fishes after the deletion process was completed.

There are additional requirements regarding the eight families needed for the Minimum Data Requirement. These additional requirements include,

A. The Family Salmonidae must be included

B. A second family of Osteichthyes (bony fish) must be included - preferably a commercially important species.

C. A third family in Phylum Chordata must be included.

D. A planktonic crustacean must be included

E. A benthic crustacean must be included 
F. An aquatic insect must be included

G. A family in a phylum other than Arthropoda or Chordata must be included

H. A second aquatic insect family or another Phylum not represented in the other 7 families.

Each of these requirements are addressed as follows;

A. Family Salmonidae

There are no species of the family (or the Order Salmoniformes) which occur or would be expected to occur at the site. However, there are species in the same class (Osteichthyes) in the National Dataset, and there are more than three families of Osteichthyes. Therefore one of the other families of Osteichthyes can substitute - for example Ictaluridae.

B. Second Family of Osteichthyes

There are five families of bony fish.

C. Third Family of Chordates

There are five families of fish.

D. A Planktonic Crustacean.

This requirement is inappropriate for an aquatic site without lentic habitat. Because no species in the Order Cladocera are found at the site, a species in the same class (Crustacea) can substitute - for example Gammarus sp. (Amphipod).

E. Benthic Crustacean

The amphipod species Crangonyx pseudogracilis fulfills the requirement.

F. Aquatic Insect

The damselfly species Argia sp. fulfills the requirement.

G. A Family in A Phylum Other Than Arthropoda or Chordata 
The bryozoan species Plumatella rostrata fulfills the requirement.

H. A Second Insect Family or a Family in Another Phylum

The worm species Lumbriculus variegatus (Phylum Annelida) fulfills the requirement.

\subsection{Calculation of Final Acute Value (FAV) and Final Chronic Value (FCV)}

Calculations are shown in Appendix D. The four genera with the lowest GMAV values were; Morone, Agosia, Physa, and Limnodrilus.

Using the Site Specific Dataset, the new FAV is $178.9406 \mathrm{ug} / \mathrm{L} \mathrm{Zn.}$

Using the Site Specific Dataset, the new FCV is calculated by dividing the Site Specific FAV by the FACR (Final Acute-Chronic Ratio) of 2.0 (the national value). The calculated FCV is 89.4703 ug/L Zn.

\subsection{Calculation of Site Specific CMC and Site Specific CCC}

Calculations are shown in Appendix D.

The new Site Specific CMC is calculated as one-half of the FAV but must be adjusted for the site hardness

The new Site Specific CCC is the same as the FCV

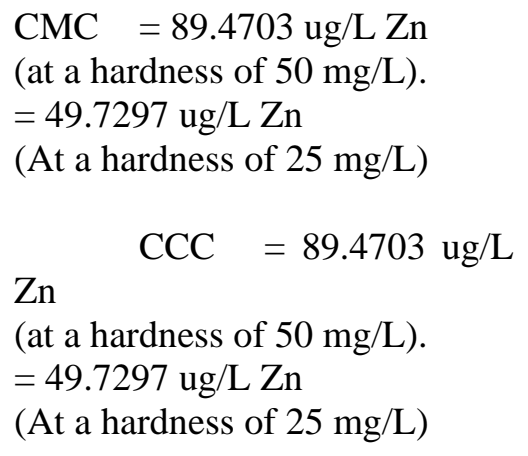

The $\mathrm{CCC}=\mathrm{CMC}$, therefore only the $\mathrm{CMC}$ is used. 


\subsection{Calculation of Site Specific Limits for Zinc for Outfall H-12}

Using the Technical Guidance on Interpretation and Implementation of Aquatic Life Metals Criteria (October 1993) and Technical Guidance Manual for Performing Waste Load Allocations Book II, Rivers and Streams (EPA/440/484/022) the Site Specific Limits for zinc can be calculated to take into account the partitioning of the metal in dissolved versus total form.

The calculations use the following input data.

$$
\begin{aligned}
& \text { CCC }(\text { Site Specific) }=49.7297 \mathrm{ug} / \mathrm{L} \mathrm{Zn}(25 \mathrm{mg} / \mathrm{L} \text { hardness }) \\
& \mathrm{CMC} \text { (Site Specific) }=49.7297 \mathrm{ug} / \mathrm{L} \mathrm{Zn}(25 \mathrm{mg} / \mathrm{L} \text { hardness }) \\
& \mathrm{DF}_{1}=1.0 \\
& \mathrm{CF}_{\mathrm{CCC}}=98.6 \\
& \mathrm{CF}_{\mathrm{CMC}}=97.8 \\
& \mathrm{k}_{\mathrm{po}}=1.25 \times 10^{6} \\
& \text { Background TSS = } 1 \mathrm{mg} / \mathrm{L} \\
& \text { Effluent TSS }=6 \mathrm{mg} / \mathrm{L} \text { (from upcoming NPDES 2C Application data) } \\
& \mathrm{a}=-0.7038
\end{aligned}
$$

The final limits are as follows;

Site Specific Maximum Zinc Limit: $\quad 153.2$ ug/L 
APPENDIX A (for recalculation procedure report)

National Dataset for Zinc 


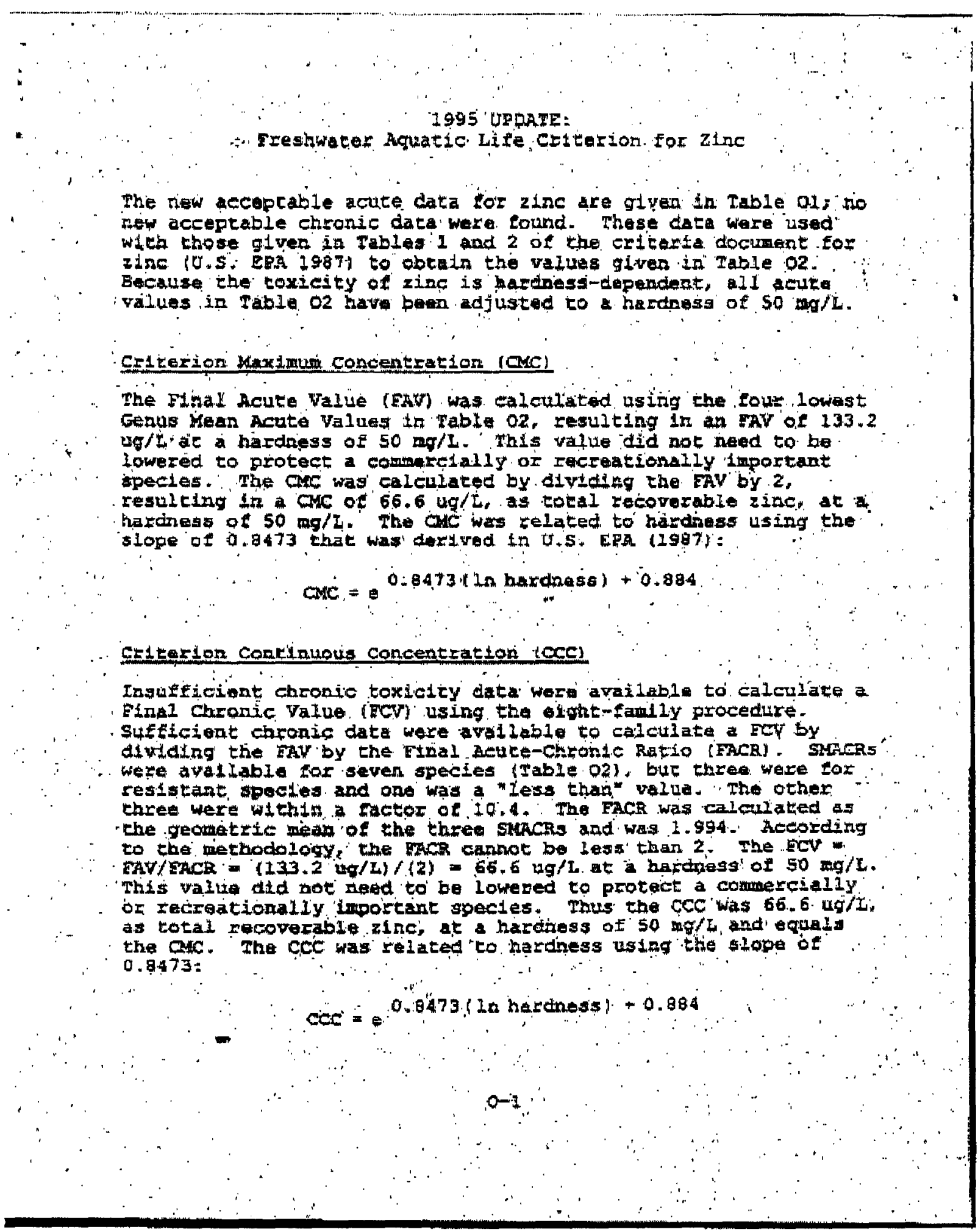

The new ecepcable acute data tor zinc are glyen in Table al; wo acceptable chronic da ca were loumd

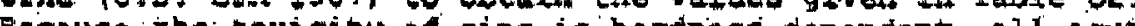
vilues in Table 02 have peen adjusted to a hardness of $\$ 0 \mathrm{mg} / \mathrm{L}$.

\section{Celiterion Haimum Concentration (OMC)}

The Flnal Acute Value (FAn) was calculated usitig the four lovest Genus Hean Acute Values ta Table o2, resulting in an Fav of 133.2 ug/L" at hardsess of $50 \mathrm{mg} / \mathrm{h}$. This value did not need to be lowezed to protect a commerelally or recreationaly important ppecles. The cac was calculared by dividing tho EAV by $z$ resulting in a CNC ot $66.6 \mathrm{ug} / \mathrm{t}$, as total zecovorable zinc, at a hardness of $50 \mathrm{mg} / \mathrm{T}$. The OAC wes telated to hardness using the slope of a.a473 that was' dertyed t7 U.5. ERA $(1997)$ :

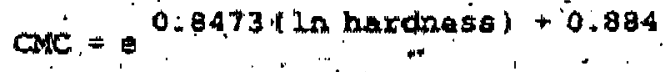



Ingufficiont chronio toxiclcy dato Hort availabl to calculare a Flnal Chronic Vafue (ECV) using the olot-fanily procedure.

Sufficient chronic data were avallable to calculate a FCV by

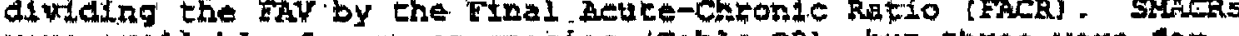


three were with1m a factor of 10,4 . The FacR was calculated as the geometrtc medn of the three siacks and was 1.994. Aceording

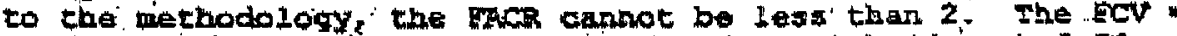
This valua did not need to' be lowered to protect a commercialiy of zecreationaliy important goectes. Thus the CCC was 66.6. ug/L

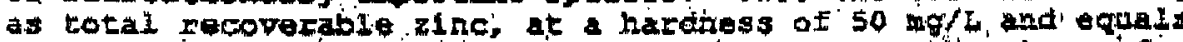
the CAC. The Cce was reluted to herdness using the sope of 0,873

$$
\cos =0.873 \text { la hardiness }+0.884
$$


Whan it equals che Cuc, the CCC is ierelevant because the cuc has aborter averaging period.

The Criterion

The procedures described in the methodology dndicate that, except possibly whexe loeally important species is very sonsitive. treshwater aquatic ofghriam ahould not be affected unacceptably 1. the ond-bour atretge concentration of zinc does not exceed the rumarical ralue (1n. ug/t) given by'tho gquation

$$
\text { OMC }=e^{0.0473(1 \mathrm{hath} \text { has })+0.084}
$$

more than once' epery three yeafs on the atrerage. 


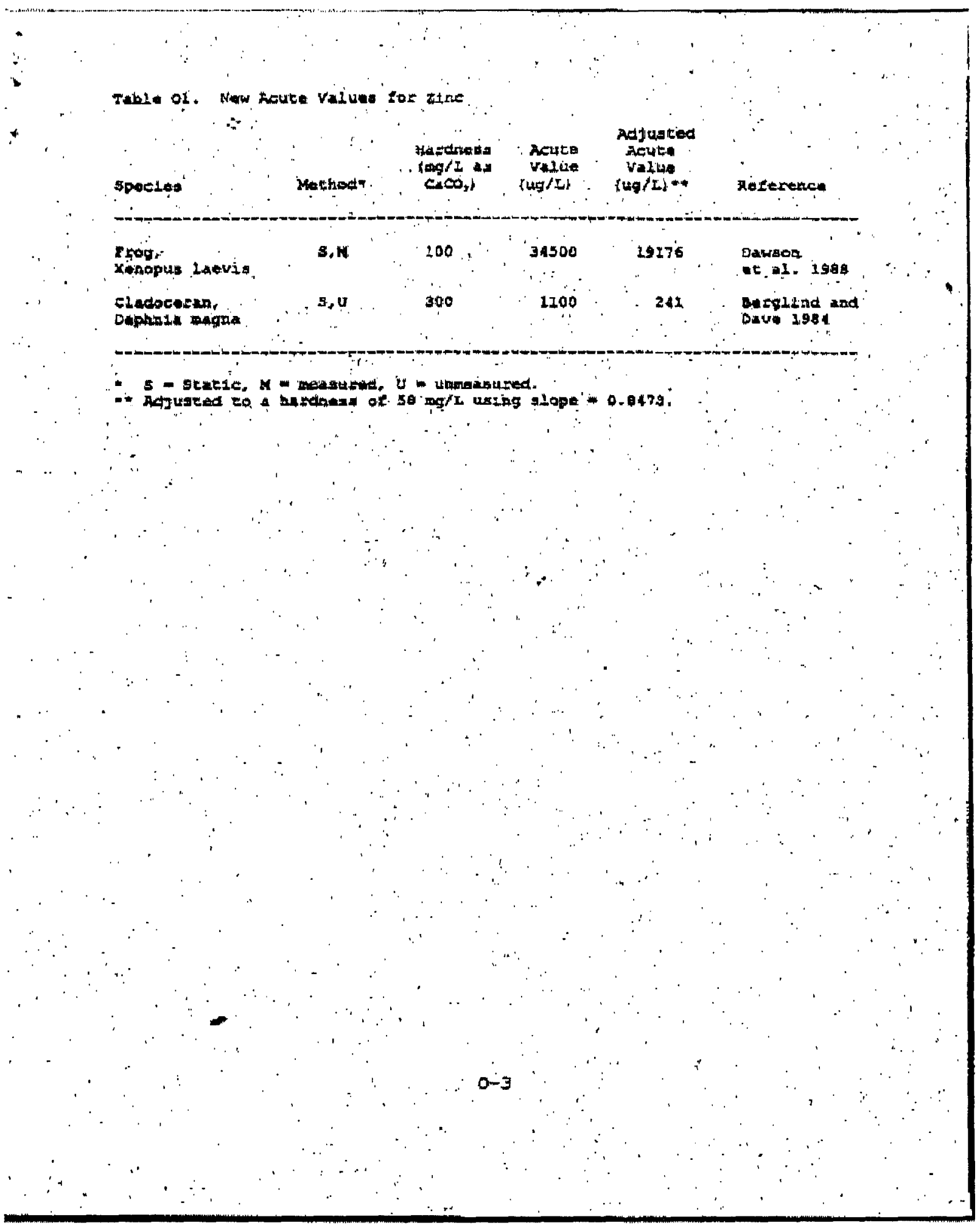

http://www.epa.gov/cgi-bin/clprint?Range=All\&StartPage=1\&EndPage=1 14\&Res=72\&Print... 6/24/03 


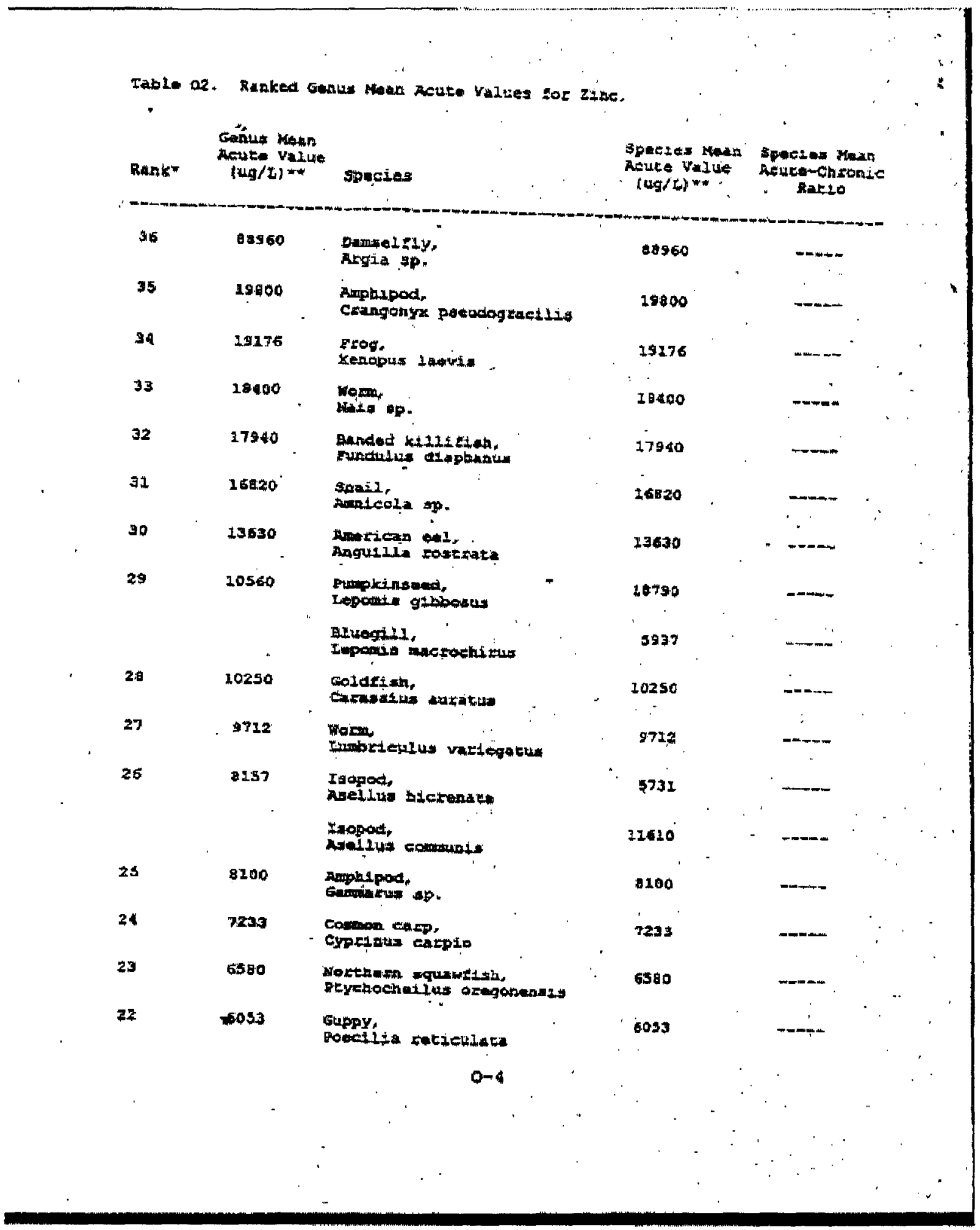

http://www.epa.gov/cgi-bin/clptint?Range=All\&StartPage=1\&EndPage=114\&Res=72\&Print... 6/24/03 




http://www.epa.gov/cgi-bin/clprint?Range=All\&StartPage=1\&EndPage=1 14\&Res=72\&Print... 6/24/03 
Tabie of. reoot.

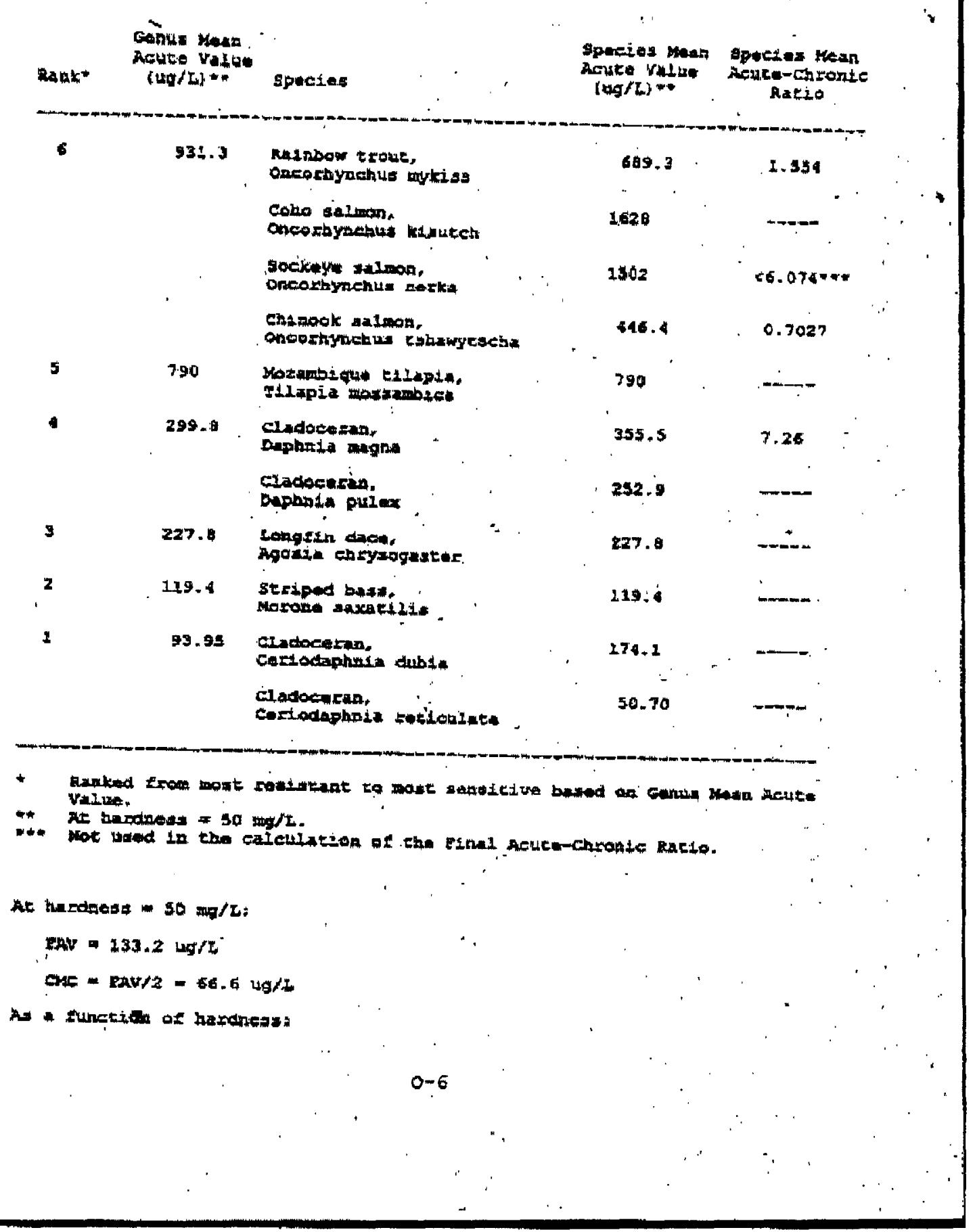

http://www.epa.gov/cgi-bin/clprint?Range=All\&StartPage=1 \&EndPage=114\&Res=72\&Print... 6/24/03 
CLARIT Web Print: 820B96001 Water Quality Criteria Documents for the Protectio... Page 111 of 114

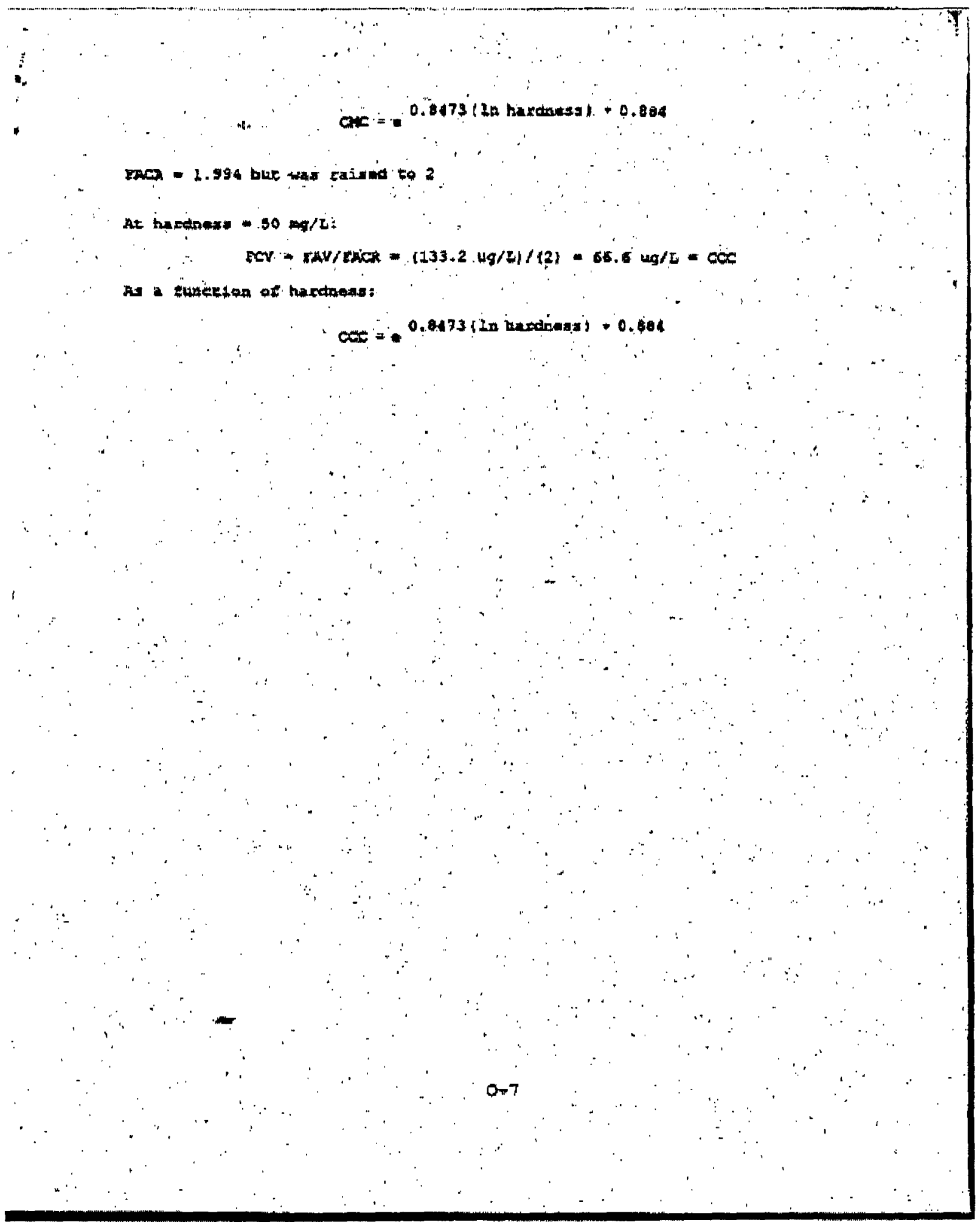

http://www.epa.gov/cgi-bin/clprint?Range=All\&StartPage=1\&EndPage=114\&Res=72\&Print... 6/24/03 


\section{References}


DOT, PCP, TPBS, and 2 ste to Daphnic magna cultured in thasd and Soft Water. BuIl. Env1 ton. Concan. Toxtcol. 33:61-68,

Dawson, D.A., E.E. Stebler, S.L. Burka, and J.A. Bancle. 1980. Evaluation of the Developmenthl Toxicity of Motal-Contaminated 5ediments Jsing Short-Term Fathead winnow and Etoo Embryo-Larta! Assaya. Environ. Foxicol, Chear. 7:27-34.

U.S. EPA. 1987. Amblem Aquatie Lite Wator Quality Criterid for Zlne. EPA 440/5-87-003, National Tochniçal Intormation service, Springtiold, VA.

http://www.epa,gov/cgi-bin/clprint?Range=All\&StartPage=1 \&EndPage=114\&Res=72\&Print... 6/24/03 
APPENDIX B (for recalculation procedure report)

\section{Deletion Process}


Recalculation Procedure - Derivation of GMAV, FAV, FCV, CMC, and CCC Metal - Zinc






\begin{tabular}{|c|c|c|c|c|c|c|c|c|c|c|c|c|c|c|c|c|c|c|c|c|}
\hline 10 & \multicolumn{4}{|c|}{ Mollusca Gastropoda Limnophila Planorbidae } & Helisoma & campanulatum & absent & no & yese & yes & yes & geners in same fomily present & $\mathrm{R}$ & 1578 & 6 & 1578 & 0.2069 & & & \\
\hline $9 b$ & \multicolumn{4}{|c|}{ Mollusca Gastropoda Limnophila Physidae } & Physa & gyring & absent & yes & yes & yee & yes & apecies in same order presecent & D & 1683 & & & & & & \\
\hline 8 & \multicolumn{4}{|c|}{ Eryozoa Phylactolaemata Plumatellida Pectinatellidae } & Pectinatella & magnifica & absent & no & no & yes & yes & Epecies in same fomily presenes & $\mathrm{R}$ & 1307 & 5 & 1307 & 0.1724 & sqrt $P$ & In GMAV & $\ln G M \mathrm{~V}^{2}$ \\
\hline 7 & \multicolumn{4}{|c|}{ Annelida Oligochaeta Tubificida Tubificidae } & Limnodrius & hoffmeisteri & present & yes & yes & yes & yes & & $\mathrm{R}$ & 1264 & 4 & 1264 & 0.1379 & 0.371 & 7.1420 & 51.00869 \\
\hline $9 a$ & \multicolumn{4}{|c|}{ Mollusca Gastropoda Limnophila Physidae } & Physa & acuta & present & yes & yes & yes & yes & & $\mathrm{R}$ & 1088 & 3 & 1088 & 0.1034 & 0.322 & 6.9921 & 48.88941 \\
\hline $6 \mathrm{~d}$ & \multicolumn{4}{|c|}{ Chordata Osteichthyes Salmoniformes Salmonidae } & Onchorhynchus & mykiss gairdneri & absent & no & no & no & yes & Epecies in rome class present & D & & & & & & & \\
\hline $6 \mathrm{c}$ & \multicolumn{4}{|c|}{ Chordata Osteichthyes Salmoniformes Salmonidae } & Onchorhynchus & kisutch & absent & no & no & no & yes & Species in same class present & $\mathrm{D}$ & & & & & & & \\
\hline $6 \mathrm{~b}$ & \multicolumn{4}{|c|}{ Chordata Osteichthyes Salmoniformes Salmonidae } & Onchorhynchus & nerka & absent & no & no & no & yes & species in same class present & D & & & & & & & \\
\hline $6 a$ & \multicolumn{4}{|c|}{ Chordata Osteichthyes Salmoniformes Salmonidae } & Onchorhynchus & tschawytscha & absent & no & no & no & yes & species in some closs present & D & 931.3 & & & & & & \\
\hline 5 & \multicolumn{4}{|c|}{ Chordata Osteichthyes Perciformes Cichlidae } & Tilapia & mossambica & absent & no & no & yes & yes & apecies in zame order presente & D & 790 & & & & & & \\
\hline $4 \mathrm{~b}$ & \multicolumn{4}{|c|}{ Arthropoda Crustacea Cladocera Daphnidae } & Daphnia & magna & absent & no & no & no & yes & species in same class present & D & & & & & & & \\
\hline $4 a$ & \multicolumn{4}{|c|}{ Arthropoda Crustacea Cladocera Daphnidae } & Daphnia & pulex & absent & no & no & no & yes & species in some class presente & D & 299.8 & & & & & & \\
\hline 3 & \multicolumn{4}{|c|}{ Chordata Osteichthyes Cypriniformes Cyprinidae } & Agosia & chrysogaster & absent & no & yes & no & yes & geners in same fomily present & $\mathrm{R}$ & 227.8 & 2 & 227.8 & 0.0690 & 0.263 & 5.4285 & 29.46827 \\
\hline 2 & \multicolumn{4}{|c|}{ Chordata Osteichthyes Perciformes Moronidae } & Morone & saxatilis & absent & no & no & yes & yes & order present not in datasest & $\mathrm{R}$ & 119.4 & 1 & 119.4 & 0.0345 & 0.186 & 4.7825 & 22.87211 \\
\hline $1 \mathrm{~b}$ & \multicolumn{4}{|c|}{ Arthropoda Crustacea Cladocera Daphnidae } & Ceriodaphia & dubia & absent & no & no & no & yes & species in same closs present & D & & & & & & & \\
\hline $1 \mathrm{a}$ & \multicolumn{4}{|c|}{ Arthropoda Crustacea Cladocera Daphnidae } & Ceriodaphnia & reticulata & absent & no & no & no & yes & opeciess in some class present & D & & & & & & & \\
\hline & & & & & & & & Genus & Fomily & Order & Closs & & & & & & sum & sum & sum & sum \\
\hline & \multicolumn{2}{|c|}{ FAV Calculations } & & & FCV Calculations & & & & & & & & & & & & 0.3448 & 1.141 & 24.3451 & .152 .2385 \\
\hline & $S^{2}=$ & 212.2202 & $s=$. & 14.5678 & & & & & & & & & & & & & & & & \\
\hline & $L=$ & 1.9296 & & & & & & & & & & & & & & & & & & \\
\hline & $A=$ & 5.1871 & & & $\mathrm{FACR}=$ & & & & & & & & 2 & national & & & & & & \\
\hline & $\mathrm{FAV}=$ & .178 .9406 & & & $\mathrm{FCV}=$ & & & & & & & & 89.4703 & & & & & & & \\
\hline & CMC $=$ & 89.4703 & at hardnes: & of $50 \mathrm{mgh}$ & $\mathrm{CCC}=$ & & & & & & & & 89.4703 & at hardne & sof & $\mathrm{mgh}$ & & & & \\
\hline & CMC $=$ & 49.7297 & at hardnes: & of $25 \mathrm{mgh}$ & $\mathrm{ccc}=$ & & & & & & & & 49.7297 & at hardne & sof & $5 \mathrm{mgh}$ & & & & \\
\hline
\end{tabular}


APPENDIX C (for recalculation procedure report)

Site Specific Dataset and Calculations of FAV and FCV 


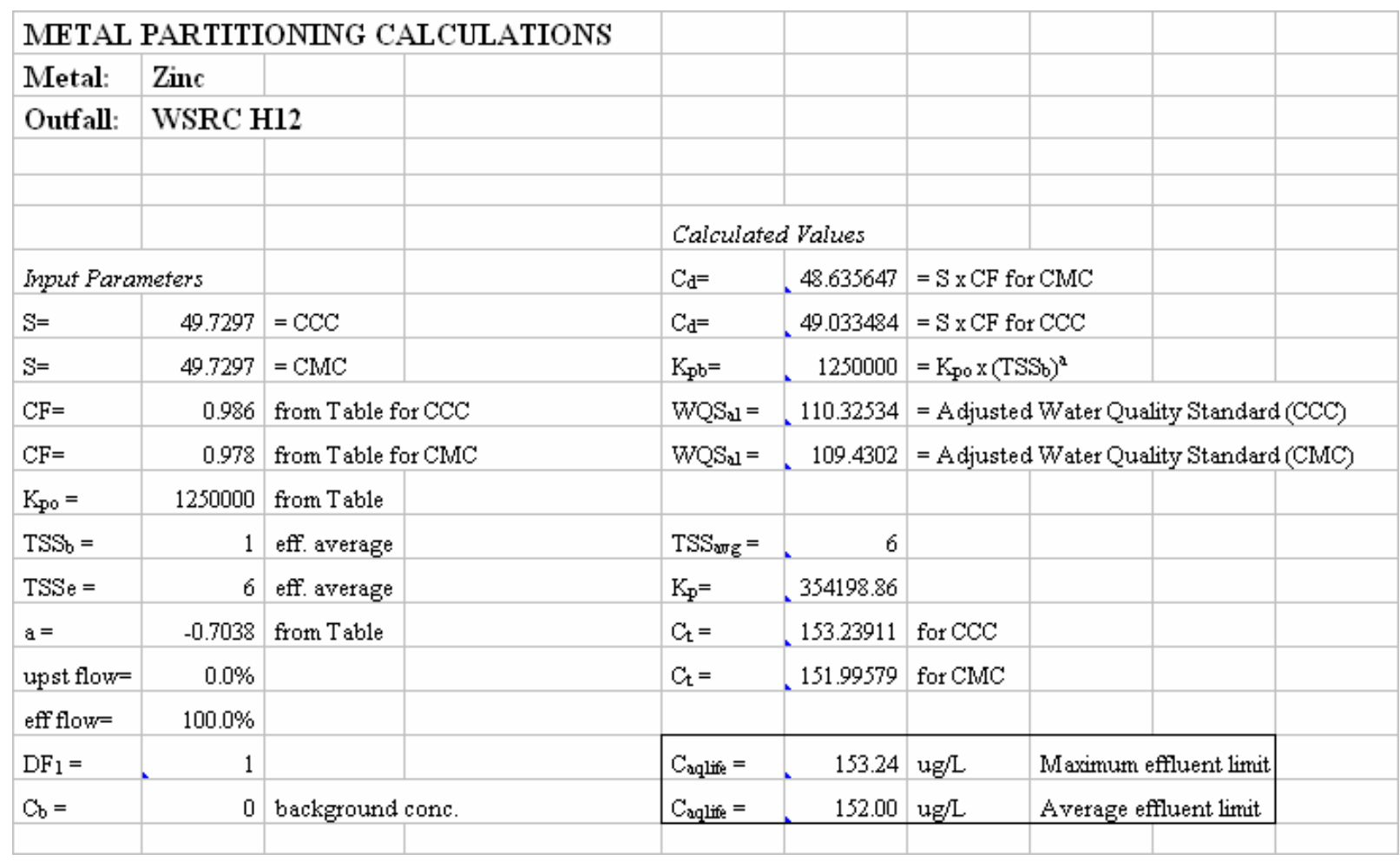


APPENDIX D (for recalculation procedure report)

\section{EPA Recalculation Procedure Protocol}


Appendix B: The Recalculation Procedure

NOTE: The National Toxics Rule (NTR) does not allow use of the Recalculation Procedure in the derivation of a sitespecific criterion. Thus nothing in this appendix applies to jurisdictions that are subject to the NTR.

The Recalculation Procedure is intended to cause a site-specific criterion to appropriately differ from a national aquatic life criterion if justified by demonstrated pertinent toxicological differences between the aquatic species that occur at the site and those that were used in the derivation of the national criterion. There are at least three reasons why such differences might exist between the two sets of species. First, the national dataset contains aquatic species that are sensitive to many pollutants, but these and comparably sensitive species might not occur at the site. Second, a species that is critical at the site might be sensitive to the pollutant and require a lower

criterion. (A critical species is a species that is commercially or recreationally important at the site, a species that exists at the site and is listed as threatened or endangered under section 4 of the Endangered Species Act, or a species for which there is evidence that the loss of the species from the site is likely to cause an unacceptable impact on a commercially or recreationally important species, a threatened or endangered species, the abundances of a variety of other species, or the structure or function of the community.) Third, the species that occur at the site might represent a narrower mix of species than those in the national dataset due to a limited range of natural environmental conditions. The procedure presented here is structured so that corrections and additions can be made to the national dataset without the deletion process being used to take into account taxa that do and do not occur at the site; in effect, this procedure makes it possible to update the national aquatic life criterion.

The phrase "occur at the site" includes the species, genera, families, cräers, classes, and phyla that:

a. are usually present at the site.

b. are present at the site only seasonally due to migration.

c. are present intermittently because they periodically return to or extend their ranges into the site.

d. were present at the site in the past, are not currently present at the site due to degraded conditions, and are expected to return to the site when conditions improve.

e. are present in nearby bodies of water, are not currently present at the site due to degraded conditions, and are expected to be present at the site when conditions improve. The taxa that "occur at the site" cannot be determined merely by sampling downstream and/or upstream of the site at one point in time. "Occur at the site" does not include taxa that were once 
present at the site but cannot exist at the site now due to permanent physical alteration of the habitat at the site resulting from dams, etc.

The definition of the "site" can be extremely important when using the Recalculation Procedure. For example, the number. of taxa that occur at the site will generally decrease as the size of the site decreases. Also, if the site is defined to be very small, the permit limit might be controlled by a criterion that applies outside (e.g., downstream of) the site.

Note: If the variety of aquatic invertebrates, amphibians, and fishes is so limited that species in fewer than eight Eamilies occur at the site, the general Recalculation Procedure is not applicable and the following special version of the Recalculation Procedure must be used:

1. Data must be available for at least one species in each of the families that occur at the site.

2. The lowest Species Mean Acute Value that is available for a species that occurs at the site must be used as the FAV.

3. The site-specific CMC and CCC mast be calculated as described below in part 2 of step $E$, which is titled "Determination of the CMC and/or CCC".

The concept of the Recalculation Procedure is to create a dataset that is appropriate for deriving a site-specific criterion by modifying the national dataset in some or all of three ways:

a. Correction of data that are in the national dataset.

b. Addition of data to the national dataset.

c. Deletion of data that are in the national dataset.

All corrections and additions that have been approved by U.S. EPA are required, whereas use of the deletion process is optional. The Recalculation Procedure is more likely to result in lowering a criterion if the net result of addition and deletion is to decrease the number of genera in the dataset, whereas the procedure is more likely to result in raising a criterion if the net result of addition and deletion is to increase the number of genera in the dataset.

The Recalculation Procedure consists of the following steps:

A. Corrections are made in the national dataset.

B. Additions are made to the national dataset.

C. The deletion process may be applied if desired.

D. If the new dataset does not satisfy the applicable Minimum Data Requirements (MDRs), additional pertinent data must be generated; if the new data are approved by the U.S. EPA; the Recalculation Procedure must be started again at step B with the addition of the new data.

E. The new CMC or CCC or both are determined.

F. A report is written.

Each step is discussed in more detail below. 


\section{A. Corrections}

1. Only corrections approved by the U.S. EPA may be made.

2. The concept of "correction" includes removal of data that should not have been in the national dataset in the first place. The concept of "correction" does not include removal of a datum from the national dataset just because the quality of the datum is claimed to be suspect. If additional data are available for the same species, the U.S. EPA will decide which data should be used, based on the available guidance (U.S. EPA 1985); also, data based on measured concentrations are usually preferable to those based on nominal concentrations.

3. Two kinds of corrections are possible:

a. The first includes those corrections that are known to and have been approved by the U.S. EPA; a list of these will be available from the U.S. EPA.

b. The second includes those corrections that are submitted to the U.S. EPA for approval. If approved, these will be added to EPA's list of approved corrections.

4. Selective corrections are not allowed. All corrections on EPA's newest list mugt be made.

B. Additions

1. Only additions approved by the U.S. EPA may be made.

2. Two kinds of additions are possible:

a. The first includes those additions that are known to and have been approved by the U.S. EPA; a list of these will be available from the U.S. EPA.

b. The second includes those additions that are submitted to the U.S. EPA for approval. If approved, these will be added to EPA's list of approved additions.

3. Selective additions are not allowed. All additions on EPA's newest list must be made:

\section{The Deletion Process}

The basic principles are:

1. Additions and corrections mast be made as per steps $A$ and $B$ above, before the deletion process is performed.

2. Selective deletions are not allowed. If any species is to be deleted, the deletion process described below mast be applied to all species in the national dataset, after any necessary corrections and additions have been made to the national dataset. The deletion process specifies which species must be deleted and which species must not be deleted. Use of the deletion process is optional, but no deletions are optional when the deletion process is used.

3. Comprehensive information must be available concerning what species occur at the site; a species cannot be deleted based 
on incomplete information concerning the species that do and do not satisfy the definition of "occur at the site".

4. Data might have to be generated before the deletion process is begun:

a. Acceptable pertinent toxicological data mut be available for at least one species in each class of aquatic plants, invertebrates, amphibians, and fish that contains a species that is a critical species at the site.

b. For each aquatic plant, invertebrate, amphibian, and fish species that occurs at the site and is listed as threatened or endangered under section 4 of the Endangered species Act, data must be available or be generated for an acceptable surrogate species. Data for each surrogate species must be used as if they are data for species that occlir at the site.

If additional data are generated using acceptable procedures (U.S. EPA 1985) and they are approved by the U.S. EPA, the Recalculation Procedure must be started again at step B with the addition of the new data.

5. Data might have to be generated after the deletion process is completed. Even if one or more species are deleted, there still are MDRs (see step D below) that must be satisfied. If the data remaining after deletion do not satisfy the applicable MDRs, additional toxicity tests must be conducted using acceptable procedures (U.S. EPA 1985) so that all MDRs are satisfied. If the new data are approved by the U.S. EPA, the Recalculation Procedure must be started again at step $B$ with the addition of new data.

6. Chronic tests do not have to be conducted because the national Final Acute-Chronic Ratio (FACR) may be used in the derivation of the site-specific Final Chronic Value (FCV). If acutechronic ratios (ACRs) are available or are generated so that the chronic MDRs are satisfied using only species that occur at the site, a site-specific FACR may be derived and used in place of the national FACR. Because a FACR was not used in the derivation of the freshwater CCC for cadmium, this CCC can only be modified the same way as a FAV; what is acceptable will depend on which species are deleted.

If any species are to be deleted, the following deletion process must be applied:

a. Obtain a copy of the national dataset, i.e., tables 1,2 . and 3 in the national criteria document (see Appendix E).

b. Make corrections in and/or additions to the national dataset as described in steps $A$ and $B$ above.

c. Group all the species in the dataset taxonomically by phylum, class, order, family, genus, and species.

d. Circle each species that satisfies the definition of "occur at the site" as presented on the first page of this appendix, and including any data for species that are surrogates of threatened or endangered species that occur at the site. 
e. Use the following step-wise process to determine which of the uncircled species must be deleted and which must not be deleted:

1. Does the genus occur at the site?

If "No", go to step 2 .

If "Yes", are there one or more species in the genus that occur at the site but are not in the dataset?

If "No", go to step 2 .

If "Yes", retain the uncircled species.*

2. Does the family occur at the site?

If "No", go to step 3 .

If "Yes", are there one or more genera in the family that occur at the site but are not in the dataset?

If "No", go to step 3 .

If "Yes", retain the uncircled species.*

3. Does the order occur at the site?

If "No", go to step 4.

If "Yes", does the dataset contain a circled species that is in the same order?

If "No", retain the uncircled species. *

If "Yes", delete the uncircled species.*

4. Does the class occur at the site?

If "No", go to step 5 .

If "Yes", does the dataset contain a circled species that is in the same class?

If "No", retain the uncircled species. *

If "Yes", delete the uncircled species.*

5. Does the phylum occur at the site?

If "No", delete the uncircled species.*

If "Yes", does the dataset contain a circled species that is in the same phylum?

If "No", retain the uncircled species."

If "Yes", delete the uncircled species."

* = Continue the deletion process by starting at step 1 for another uncircled species unless all uncircled species in the dataset have been considered.

The species that are circled and those that are retained constitute the site-specific dataset. (An example of the deletion process is given in Figure BI.)

This deletion process is designed to ensure that:

a. Each species that occurs both in the national dataset and at the site also occurs in the site-specific dataset. 
b. Each species that occurs at the site but does not occur in the national dataset is represented in the site-specific dataset by all species in the national dataset that are in the same genus.

c. Each genus that occurs at the site but does not occur in the national dataset is represented in the site-specific dataset by all genera in the national dataset that are in the same family.

d. Each order, class, and phylum that occurs both in the national dataset and at the site is represented in the site-specific dataset by the one or more species in the national dataset that are most closely related to a species that occurs at the site.

\section{Checking the Minimum Data Requirements}

The initial MDRs for the Recalculation Procedure are the same as those for the derivation of a national criterion. If a specific requirement cannot be satisfied after deletion because that kind So do of species does not occur at the site, a taxonomically similar species must be substituted in order to meet the eight MDRs:

If no species of the kind required occurs at the site, but a species in the same order does, the MDR can only be satisfied Natinal by data for a species that occurs at the site and is in that order; if no species in the order occurs at the site, but a species in the class does, the MDR can only be satisfied by data for a species that occurs at the site and is in that class. If no species in the same class occurs at the site, but a species in the phylum does, the MDR can only be satisfied by data for a species that occurs at the site and is in that phylum. If no species in the same phylum occurs at the site, any species that occurs at the site and is not used to satisfy a different MDR can be used to satisfy the MDR. If additional data are generated using acceptable procedures (U.S. EPA 1985) and they are approved by the U.S. EPA, the Recalculation. Procedure must be started again at step B with the addition of the new data.

If fewer than eight families of aquatic invertebrates, amphibians, and fishes occur at the site, a Species Mean Acute Value must be available for at least one species in each of the families and the special version of the Recalculation Procedure described on the second page of this appendix must be used.

E. Determining the $C M C$ and/or $C C C$

1. Determining the FAV:

a. If the eight family MDRs are satisfied, the site-specific FAV must be calculated from Genus Mean Acute Values using 
the procedure described in the national aquatic life guidelines (U.S. EPA 1985).

b. If fewer than eight families of aquatic invertebrates, amphibians, and fishes occur at the site, the lowest Species Mean Acute Value that is available for a species that occurs at the site must be used as the FAV, as per the special version of the Recalculation Procedure described on the second page of this appendix.

2. The site-specific CMC must be calculated by dividing the sitespecific FAV by 2 . The site-specific FCV must be calculated by dividing the site-specific FAV by the national FACR (or by a site-specific FACR if one is derived). (Because a FACR was not used to derive the national CCC for cadmium in fresh water, the site-specific CCC equals the site-specific FCV.)

3. The calculated FAV, CMC, and/OI CCC must be lowered, if necessary, to (1) protect an aquatic plant, invertebrate, amphibian, or fish species that is a critical species at the site, and (2) ensure that the criterion is not likely to jeopardize the continued existence of any endangered or threatened species listed under section 4 of the Endangered Species Act or result in the destruction or adverse modification of such species' critical habitat.

F. Writing the Report

The report of the results of use of the Recalculation Procedure must include:

1. A list of all species of aquatic invertebrates, amphibians, and fishes that are known to "occur at the site", along with the source of the information.

2. A list of all aquatic plant, invertebrate, amphibian, and fish species that are critical species at the site, including all species that occur at the site and are listed as threatened or endangered under section 4 of the Endangered. Species Act.

3. A site-specific version of Table 1 from a criteria document produced by the U.S. EPA after 1984 .

4. A site-specific version of Table 3 from a criteria document produced by the U.S. EPA after 1984 .

5. A list of all species that were deleted.

6. The new calculated FAV, CMC, and/or CCC.

7. The lowered FAV, $\mathrm{CMC}$, and/or $\mathrm{CCC}$, if one or more were lowered to protect a specific species.

\section{Reference}

U.S. EPA. 1985. Guidelines for Deriving Numerical National Water Quality Criteria for the Protection of Aquatic Organisms and Their Uses. PB85-227049. National Technical Information Service, springfield, VA. 
Figure B1: An Example of the Deletion Process Using Three Phyla

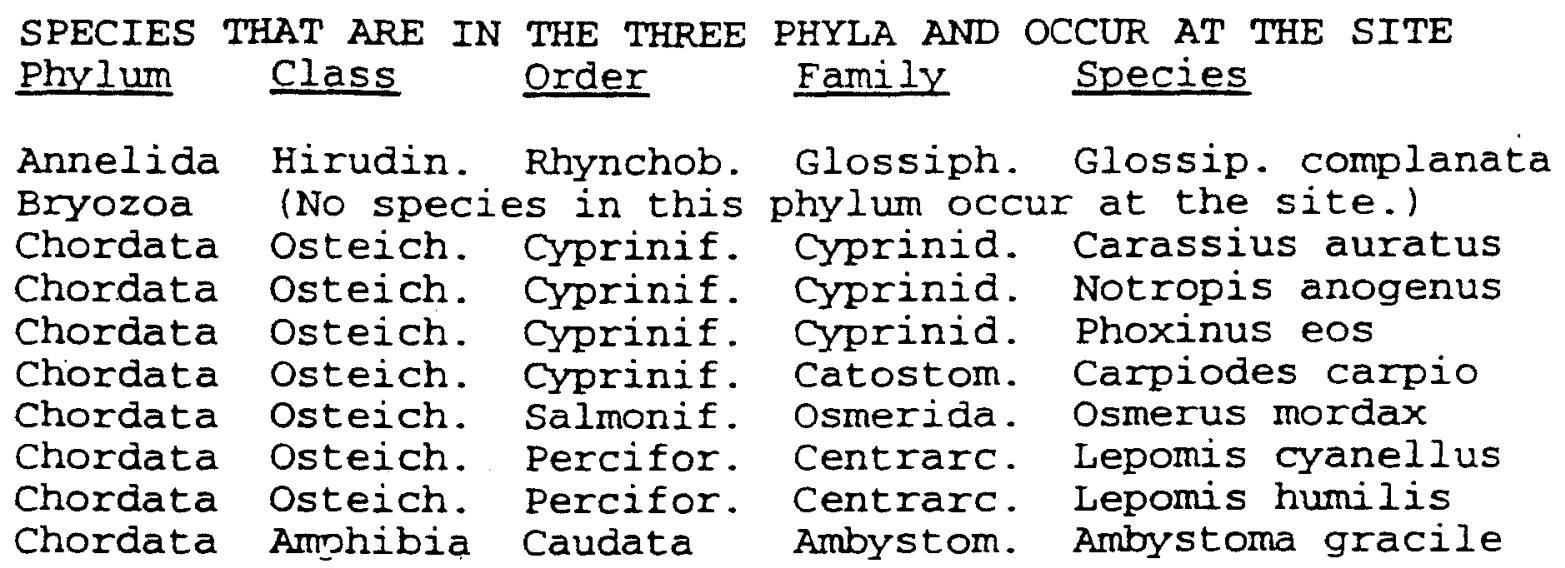

\begin{tabular}{|c|c|c|c|c|c|}
\hline $\begin{array}{l}\text { ECIES } \\
\text { lum }\end{array}$ & $\begin{array}{l}\text { LAT ARE IN } \\
\text { Class }\end{array}$ & $\begin{array}{l}\text { THE THREE } \\
\text { Order }\end{array}$ & $\begin{array}{l}\text { A AND } \\
\text { nily }\end{array}$ & $\begin{array}{l}\text { THE NATIO } \\
\text { Species }\end{array}$ & \\
\hline $\begin{array}{l}\text { Ea } \\
\text { ta } \\
\text { Ea } \\
\text { Ea } \\
\text { Ea } \\
\text { ta } \\
\text { ta } \\
\text { Ea } \\
\text { Ea }\end{array}$ & $\begin{array}{l}\text { Ost } \\
\text { Ost } \\
\text { Ost } \\
\text { Ost } \\
\text { Ost } \\
\text { Ost } \\
\text { Ost }\end{array}$ & $\begin{array}{l}\text { Cyprinif. } \\
\text { Cyprinif. } \\
\text { Cyprinif. } \\
\text { Cyprinif. } \\
\text { Cyprinif. } \\
\text { Cyprinif. } \\
\text { Salmonif. } \\
\text { Percifor. } \\
\text { Percifor. }\end{array}$ & $\begin{array}{l}\mathrm{Cy} \\
\mathrm{Cy} \\
\mathrm{Cy} \\
\mathrm{Cy} \\
\mathrm{Cy} \\
\mathrm{Ca} \\
\mathrm{Sa} \\
\mathrm{Ce} \\
\mathrm{Ce} \\
\mathrm{Pe}\end{array}$ & $\begin{array}{l}\text { Tubifex tubifex } \\
\text { Lophopod. carteri } \\
\text { Petromyzon marinus } \\
\text { Carassius auratus } \\
\text { Notropis hudsonius } \\
\text { Notropis stramineus } \\
\text { Phoxinus eos } \\
\text { Phoxinus oreas } \\
\text { Tinca tinca } \\
\text { Ictiobus bubalus } \\
\text { Oncorbynchus mykiss } \\
\text { Lepomis cyanellus } \\
\text { Lepomis macrochirus } \\
\text { Perca flavescens } \\
\text { Xenopus laevis }\end{array}$ & \\
\hline
\end{tabular}

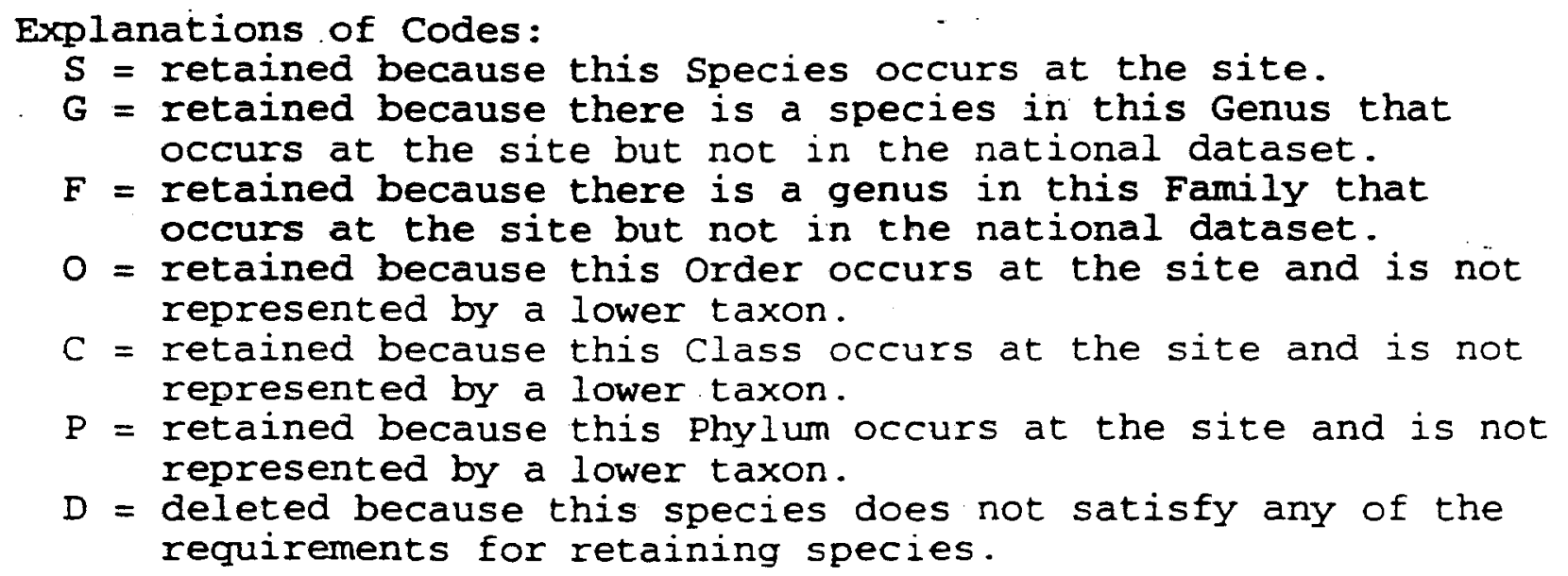

